\title{
Regulation And Macroeconomic Performance ${ }^{*}$
}

\author{
Norman V. Loayza \\ The World Bank
}

\author{
Ana María Oviedo \\ University of Maryland
}

\author{
Luis Servén \\ The World Bank
}

September 2004

\begin{abstract}
Regulation is purportedly enacted to serve specific social purposes. In reality, however, it follows a more complex political economy process, where legitimate social goals are mixed with the objectives of particular interest groups. Whatever its justification and objectives, regulation can have potentially significant macroeconomic consequences, by helping or hampering the dynamics of economic restructuring and resource reallocation that underlie the growth process. This paper provides an empirical analysis of the macroeconomic impact of regulation. It first characterizes the stylized facts on regulation across the world, using a set of newly constructed, comprehensive indicators of regulation in a large number of countries in the 1990s. Using these indicators, the paper studies the effects of regulation on economic growth and macroeconomic volatility employing cross-country regression analysis. In particular, the paper considers whether the effects of regulation are affected by the country's level of institutional development. Finally, the analysis controls for the likely endogeneity of regulation with respect to macroeconomic performance. The paper concludes that a heavier regulatory burden reduces growth and increases volatility, although these effects are smaller the higher the quality of the overall institutional framework.
\end{abstract}

JEL classification: H11, K20, K30, E32, O40.

Keywords: Regulation, government structure, volatility, economic growth.

\footnotetext{
* This research has been supported by the World Bank's Latin America Regional Studies Program and the Poverty Reduction and Economic Management Network. We are very grateful to Raphael Bergoeing, Caroline Freund, John Haltiwanger, Patricia Macchi, Andrea Repetto, Roberto Zagha, and participants in the EGDI-WIDER Conference on the Informal Sector (Helsinki, 2004) for useful comments and data. The views expressed herein are those of the authors and do not necessarily represent those of the institutions to which they are affiliated.
} 


\section{Introduction}

Regulation of goods and factor markets is purportedly enacted to serve specific social purposes. In reality, however, it obeys a more complex political economy process, where legitimate social goals are mixed with the objectives of particular interest groups concerning the level and distribution of rents. But regulation also has potentially important effects on economic performance, which have attracted increasing attention in recent years. According to a commonly held view, excessive regulation is the prime cause of Europe's macroeconomic underperformance over the last decade vis-à-vis the United States (see Blanchard 2004). Likewise, intricate regulation and its arbitrary enforcement are listed by the World Bank (2005) among the key obstacles to growth in developing countries.

The key mechanism through which regulation affects aggregate economic performance is the Schumpeterian process of "creative destruction" at the core of the growth engine in market economies -- the continuous restructuring and factor reallocation through which new technologies replace the old (Aghion and Howitt 1992, Caballero and Hammour 1996). There is ample evidence that the shift of resources away from less productive and towards more efficient production units accounts for much of the observed growth in aggregate productivity. ${ }^{1}$ The macroeconomic impact of regulation arises primarily from its effects on the dynamics of restructuring. ${ }^{2}$ In particular, regulatory barriers that disrupt the process of resource reallocation tend to cause a deterioration in aggregate economic performance, by allowing low-productivity activities to survive too long, and discouraging the adoption of new high-productivity activities (Caballero and Hammour 1998).

A recent empirical literature has examined the impact of various kinds of regulation on proximate determinants of GDP growth - productivity, investment and employment finding for the most part negative effects. In this vein, Nicoletti and Scarpetta (2003) find that product market regulation lowers multifactor productivity growth in OECD countries, while Bassanini and Ernst (2002) report a negative effect of regulation on innovation. Alesina et al. (2002) likewise find that product market regulations have a negative effect

\footnotetext{
${ }^{1}$ See for example Haltiwanger (2000) and Ahn (2001).

2 For theoretical linkages between regulation and firm dynamics see, for instance, Pakes and McGuire (1994), Hopenhayn (1992) and Bergoeing et al., (2004). See also Blanchard and Giavazzi (2001) for an insightful model highlighting the macroeconomics of labor and product market regulation.
} 
on private investment in OECD economies. In turn, Nicoletti et al. (2001a,b) provide empirical evidence that anti-competitive regulation reduces employment in a panel of industrial countries, while CEPR-IFS (2003) find that increased product market competition encouraged by deregulation raises both investment and employment in a panel data set covering OECD countries. ${ }^{3}$ Regarding labor regulation Blanchard and Wolfers (2000) and Heckman and Pagés (2000) find that hiring and firing restrictions discourage employment creation in European and Latin American economies, respectively. Moreover, simulations for OECD economies suggest that the effects of output and labor regulation on aggregate investment and employment are quantitatively considerable (Bayoumi, Laxton and Pesenti 2004).

A few empirical studies tackle the impact of regulation and deregulation on aggregate growth in a cross-country setting. Koedijk and Kremers (1996) find a negative association between measures of product market regulation and GDP growth among 11 European countries. In contrast, they find that labor regulations have no significant association with growth performance. Dutz and Hairy (1999) apply extreme-bounds analysis to estimate the contribution to growth of a variety of (mostly subjective) regulation and competition indicators in a sample of industrial and developing countries. They find significant effects of measures of anti-trust policy and the average age of large firms (taken as proxy for entry and exit barriers). However, Card and Freeman (2002) fail to find any significant association between subjective measures of economic regulation and growth performance in a panel regression covering OECD countries over 1970-99.

In this paper we present a comprehensive empirical assessment of the macroeconomic effects of regulation in a large sample of industrial and developing countries. We focus on two key measures of macroeconomic performance, namely the growth and volatility of real GDP. Our empirical strategy relies on the inclusion of suitable indicators of regulation into simple empirical equations relating these aggregate performance measures to standard control variables taken from the macroeconomics and growth literature. While we do not characterize the specific channel through which the

\footnotetext{
3 In contrast, CEPR-IFS (2003) finds that the impact of product market competition on aggregate productivity growth is less robust: the effect is positive only when the cross-country variation is taken into consideration, and negative when the estimates are computed using the within-country variation.
} 
aggregate impact of regulation unfolds, our approach allows us to obtain a summary measure of the magnitude of such impact which combines the action of the various intervening mechanisms - factor reallocation, capital accumulation, competition and innovation - considered in the literature.

The paper extends the literature along four dimensions. First, we provide a broad characterization of business regulation around the world. Drawing from a variety of data sources, we build a set of synthetic indicators capturing the regulations that firms face in the multiple dimensions of their activity - entry and exit, trade, taxes, contract enforcement, labor and finance. One novel feature of these indicators is that they go beyond de jure regulation and incorporate, to a significant extent, the burden of de facto regulation. Using this information, we document the stylized facts of regulation across the world, regarding the extent of regulation in different countries, its relation with per capita income, and the observed relationship between different types of regulation.

Second, unlike the existing literature on the macroeconomic impact of regulation, which has focused almost exclusively on aggregate growth or its proximate determinants, we examine also the effect of regulation on aggregate volatility. This is of independent interest for several reasons. On the one hand, recent literature suggests that excessive regulation can lead to microeconomic inflexibility (Caballero, Engel and Micco 2004). This tends to hamper the economy's ability to absorb shocks requiring microeconomic reallocation, thus amplifying their aggregate impact. On the other hand, certain kinds of product market regulation - such as those on entry and exit - act as barriers to firm creation and destruction and might have the opposite effect, attenuating cyclical output fluctuations. Hence, the impact of regulation on volatility is a priori ambiguous, and can be established only empirically. To our knowledge, this is the first paper addressing this issue.

Third, we take into account the fact that the effects of regulation are likely to depend not only on the quantity of regulation, but also on its quality. There are good reasons for this. On analytical grounds, certain types of regulation - such as those designed to enhance competition in goods or financial markets - should be expected to 
exert beneficial effects on economic performance, rather than adverse ones. ${ }^{4}$ More generally, countries with better institutions tend to create regulatory environments genuinely aimed to improve business conditions rather than privilege a few interest groups. They are also more likely to enforce regulation in a transparent and even-handed manner, limiting the regulator's margin for arbitrariness and corruption that can place many firms at a disadvantage, sometimes forcing them to operate in the informal sector. ${ }^{5}$ All these arguments suggest that the quality of regulation is likely to be closely related to overall governance quality, and thus in our experiments we use standard governance indicators to capture regulatory quality.

Fourth, our empirical approach also allows for the possibility that aggregate performance may itself be one of the factors weighing on policy makers' decision to adopt regulatory measures. Low growth or excessive macroeconomic volatility may make it more likely for the authorities to introduce or tighten regulation - e.g., adopting strict labor regulations or raising firm exit barriers in the hope of containing job and output losses in downswings. Thus, any observed association between regulation and macroeconomic performance could reflect causality from the latter to the former rather than (or in addition to) the reverse. To ensure that our results reflect the causal effect of regulations on growth and volatility, we also report empirical results from instrumental variable estimations.

Before proceeding, we should note one important caveat of our analysis. Our objective is limited to studying the macroeconomic consequences of regulation. It is not our purpose to evaluate the success of specific regulations at meeting their stated objectives, nor do we pretend to judge the impact of regulation on social welfare dimensions beyond the influence of economic growth and volatility.

The rest of the paper is organized as follows. Section II describes the synthetic regulation indicators and presents some stylized facts concerning the patterns of regulation across industrial and developing countries. Section III reports estimates of the impact of regulation on growth and aggregate volatility. Section IV offers some concluding remarks.

\footnotetext{
${ }^{4}$ For instance, Klapper et al. (2004) find that certain regulations, such as entry and exit barriers, have negative effects on firm entry, whereas others, like investors' rights regulations, have positive effects.

${ }^{5}$ See for instance De Soto (1986).
} 


\section{Business regulation around the world}

We now turn to the description of the nature and extent of business regulation around the world. In this section, we first give an account of the areas of economic activity under regulation on which we focus and describe how we measure regulation in each of them. Next, we discuss differences in regulation intensity across regions of the world and give a preview of the relationship between regulation and macroeconomic variables.

\section{A typology of regulation}

Our departure point is the assumption that the macroeconomic impact of business regulation arises from its effects on firm dynamics. Therefore, we select the relevant areas of business regulation by looking for them at the three stages of the life of a firm: entry, growth, and exit. In most countries, all three are regulated to some degree; for instance, in virtually all countries entrepreneurs need to follow a number of procedures to start a firm, although the burden of the administrative process varies widely across countries. ${ }^{6}$ Once a firm is legally registered and allowed to operate, its decisions are conditioned by regulations on hiring and firing workers, taxes, safety standards, environmental regulations, interest rate controls, trade barriers, legal procedures, etc. ${ }^{7}$ Finally, a firm going out of business must again follow a sometimes costly and lengthy procedure.

\section{How does regulation alter firm dynamics?}

Regulation certainly affects firms' decisions, but does it improve the conditions for their xtivities or, on the contrary, does it impose unnecessary restrictions that increase costs and reduce productivity? Although we do not rule out the first option, we should recognize the potentially distortive effects of regulation on firms' decisions and ultimately on macro performance. We consider seven main areas of a firm's activity subject to regulation: entry, exit, labor markets, fiscal burden, international trade, financial markets, and contract enforcement; for each area, we construct an index of the severity of regulation. Rather than restricting our measures of regulation strictly to legal directives, we want to account for the practical restrictions and complications brought about by certain rules. The regulation of entry index aims at capturing the actual difficulty that an

\footnotetext{
${ }^{6}$ See Djankov et al. (2002).

${ }^{7}$ Some regulations have also "indirect" effects on firm dynamics, for instance, Berkowitz and White (2002) find that personal bankruptcy laws play an important role in small firms' access to credit in the U.S.
} 
entrepreneur faces to start a business, from a legal perspective as well as in practice. The index of bankruptcy regulation should reflect the speed and efficiency of the bankruptcy process; in particular how well the justice system establishes priorities for creditors and enforces compensation. With the labor market regulation index, we want to measure how difficult it is for a firm to adjust its labor force. The measure should also include information about the wage setting system of the country, and the power of organized labor. The index of fiscal burden aims at measuring the burden to firms imposed by taxation and fiscal spending, an element that determines in many cases a firm's choice of location. With the trade regulation index we look at how much countries protect domestic producers; specifically we are interested in measuring the cost for the entire economy of protecting a selected group of producers. The financial markets regulation index should capture how easy a firm's access to capital markets is. For instance, special credit conditions for some industries, or interest rate controls can reduce the availability of credit to more deserving firms and distort incentives for investment. Finally, the contract enforcement index is a general measure of how easily firms can turn to the justice system to resolve legal disputes.

\section{Measuring regulation}

We use six data sources for the construction of our indices: Doing Business (The World Bank Group), Index of Economic Freedom (The Heritage Foundation), Economic Freedom of the World (The Fraser Institute), Labor Market Indicators Database (M. Rama and R. Artecona, 2000), The Corporate Tax Rates Survey (KPMG), and hternational Country Risk Guide (The PRS Group). These sources cover the largest number of countries and areas under regulation, and their measures use a clear methodology and are straightforward. Except for the Labor Market Indicators Database, all sources are public. Our sample covers 76 countries. $^{8}$

In most cases, data are based on surveys conducted in a single year (in the late 1990's) in a large group of countries; for components with observations for more than one

\footnotetext{
${ }^{8} \mathrm{We}$ do not consider here the heterogeneity of regulation within countries. This can be important in some cases, such as the added burden of local taxation in federal systems. At present, however, very few data sources provide information on regulation at the regional level. One of these sources is the Investment Climate Survey of The World Bank, which records data on investment climate and activities of over 14,000 firms in about 30 countries.
} 
year, we use average values over the period. Therefore, our indices should be interpreted as average regulation levels in the late 1990's. We should note, however, that regulation tends to stay constant over long periods of time. ${ }^{9}$

Each index measures the intensity of the regulatory system on a scale from 0 to 1 (1 representing the heaviest regulation). In order to be able to combine all components, we apply the following standardization formula to each one of them:

$$
\begin{gathered}
\frac{X_{i}-X_{\min }}{X_{\max }-X_{\min }} \text {,if higher values of } X \text { indicate heavier regulation and } \\
\frac{X_{\max }-X_{i}}{X_{\text {max }}-X_{\min }} \text {, if lower values of } X \text { indicate heavier regulation }
\end{gathered}
$$

We then obtain an index of regulation for each area of business activity outlined above by matching each component to one activity, and taking the simple average of the components within each activity.

The entry regulation index combines the number of legal steps required to register a new business with an indicator of the overall legal burden of registration and willingness of the government to facilitate the process and intervene minimally. The index of labor regulation combines the percentage of workers that belong to a union, the minimum mandatory working conditions, and the degree of hiring and firing flexibility granted by the law. The index of fiscal burden measures direct taxation --that is, the maximum tax rate applied to individuals and businesses-- and fiscal spending. The index of trade barriers combines an indicator of average tariffs with one that measures the existence of hidden import barriers, and an indicator of the additional cost of importing generated by mandatory administrative procedures (tariff costs, fees for obtaining licenses, bank fees, etc.). The index of financial markets regulation measures the degree of government intervention in the financial market, interest rate controls, ownership of banks, entry barriers, restrictions in securities markets, and competition between domestic and foreign banks. The index of contract enforcement combines the number of legal procedures for disputes that are taken to court, with a measure of the stability of the bureaucracy and its sensitivity to political changes in the government. Finally, the index of bankruptcy regulation measures the efficiency of the bankruptcy process by combining the time and

\footnotetext{
${ }^{9}$ See, for instance, Bolaky and Freund (2004).
} 
cost of insolvency, the enforcement of priority of claims, the extent to which the efficient outcome is achieved, and the degree of court involvement in the process.

Rather than just summarize de jure regulation, our measures capture to a large extent its actual burden on economic agents. However, a caveat is necessary: our indices, as well as their components, do not provide full information about the quality of regulation; in particular, they do not reflect completely either the extent to which regulation corrects for market failures or the political and social context in which regulation is implemented. These distinctions are important because, as already noted, the economic impact of regulation may be dependent on institutional country characteristics. ${ }^{10}$ We attempt to account for this issue in the econometric section of the paper.

\section{Regulation around the world}

How do entry, growth and exit regulations vary across world regions? Although governments oversee and extract revenues from business activities in all countries --and quite heavily in many--, there is considerable variation in the intensity of regulation across regions. Table 1 presents the summary statistics of the seven indices mentioned above. Industrial countries tend to adopt heavy fiscal regulation, medium labor regulation, and low regulation in trade, financial markets, entry, bankruptcy, and contract enforcement. Developing regions cannot be characterized as simply as the OECD as they show varying patterns for each type of regulation. For example, with respect to the OECD, labor regulation is almost $16 \%$ lower in East Asia and the Pacific, while $26 \%$ higher in Latin America and the Caribbean. ${ }^{11}$ The most striking difference between the OECD and developing-country groups is in trade regulation, where all developing regions have indices at least $150 \%$ higher than the OECD group, reaching an enormous $710 \%$ difference in the case of the Middle East and Northern Africa. On the other hand, in the case of fiscal regulation, differences across regions are not nearly as pronounced.

Which countries regulate the most? Although heavy regulators are mainly found among developing countries, OECD countries rank highest in fiscal regulation: Belgium ranks number one, Italy number two, and France is number four (Syria is number three).

\footnotetext{
${ }^{10}$ See, for instance, Claessens and Klapper (2002).

11 These numbers are calculated on the basis of Table 1, for example, the mean of the "Labor" indicator is 0.44 in the OECD and 0.37 in the EAP region, so that the difference is $(0.37-0.44) * 100 / 0.44=-15.9 \%$.
} 
The country with the lowest fiscal-regulation score is Haiti. ${ }^{12}$ On average, labor regulation is highest in Latin America and the Caribbean, followed by the Middle East and Northern Africa. OECD countries do not have high labor regulation in average, but they do exhibit large dispersion: over the entire sample (all regions combined), Portugal has the highest labor regulation score while the United States has the lowest. In the remaining areas OECD countries always occupy the bottom of the distribution. For instance, The Netherlands reaches the lowest score in financial regulation, Finland in bankruptcy and trade, Iceland in contract enforcement, and Canada in entry regulation. The harshest regulatory environments are in Sierra Leone (contract enforcement), Haiti (entry), Syria and Iran (financial markets), Tunisia and Papua New Guinea (trade), and The Philippines (bankruptcy).

Table 2 shows simple correlations between the regulation indices. The strongly positive correlations among all but the fiscal burden and labor indices suggest that regulation policy comes in "packages." Judging from these correlations, we can distinguish three regulation categories: fiscal burden, labor, and "product market," where the latter is a composite of the entry, trade, financial markets, bankruptcy, and contract enforcement indices. ${ }^{13}$ We obtain the product market index by averaging the scores of the five components; we also compute an "overall" regulation index by averaging the scores of all seven components. We choose to give equal weights to all components despite the strong correlation among the first five because we don't have any priors about the importance of labor market or fiscal regulation relative to the others.

The arrangement of the regulation indices into these three groups receives additional statistical support from factor analysis. The first three principal components obtained from factor analysis of the seven basic indices explain, respectively, 53\%, 15\%, and $12 \%$ of their overall variance. These principal components have a close one-to-one match with the indices resulting from the three categories. For the first principal component, the five "product market" regulation indices receive high and similar loadings, and not so the labor and fiscal regulation indices. For the second principal component, the

\footnotetext{
${ }^{12}$ Keep in mind that the rank of a country is relative to the sample, therefore changing the composition of the sample will most likely alter the ranking as well.

${ }^{13}$ The term "product market regulations" is taken from Nicoletti et al. (2000).
} 
labor regulation index receives the highest loading, while the other six indices get only low positive or negative weights. Analogously, the third principal component loads heavily only on the tax regulation index. The close connection between the principal components and our regulation categories is clearly demonstrated by the pattern of correlation coefficients shown in Table $2 .^{14}$

Figure 1 provides a regional comparison of the overall, product market, fiscal, and labor regulation indices. In addition, figure 2 depicts scatter plots of these indices against the (the $\log$ of) GDP per capita of all countries in the sample. Looking at the first three panels, it becomes clear that employment regulation, fiscal burden, and product market regulation stand apart from each other. Indeed, while there seems to be little relation between a country's average income and the strength of labor regulation, the relationship with income is positive and significant in the case of fiscal burden and clearly negative in the case of product market regulation. The overall regulation index is negatively related to per capita GDP, which is not surprising given the large weight of product market regulation in the overall index.

\section{Regulation and governance}

The effect of regulation on firm dynamics and, ultimately, macroeconomic performance is likely to depend on the institutional context in which regulation is enacted. For example, countries with better institutions create regulatory environments that actually try to improve business conditions rather than privilege a few interest groups; they also limit the interaction between regulation and abuses of power in the public sector that place many firms in disadvantage, sometimes forcing them to operate in the informal sector (see for instance De Soto, 1986).

We use an index of "go vernance quality" in order to assess the quality of regulation itself and the general context that determines how regulation functions. We construct this index using measures from the International Country Risk Guide, which evaluates a country's risk for international investment by looking at its social and political situation. Specifically, we average the values of indicators measuring the absence of corruption in

\footnotetext{
${ }^{14}$ Other studies, such as Nicoletti et al. (2000) or Klapper et al. (2004) also use factor analysis to decompose regulation measures, and they further replace the measures with their principal components in the regressions. Because of the strong correlation between the components and our indices (see Table 2), we choose not to use the principal components in our regressions.
} 
the political system, the prevalence of law and order, and the level of democratic accountability. ${ }^{15}$

\section{Regulation and Macroeconomic Performance}

Having described how the regulatory environment varies across countries, our objective for this section is examining whether regulations have an impact on macroeconomic performance. Regulations are imposed for a variety of reasons. Officially, they are enacted to serve specific social purposes, from consumer health safety to the protection of domestic employment. In reality, however, the imposition of regulation follows a more complex political economy process, where legitimate social goals are mixed with the objectives of particular interest groups (see Djankov, La Porta, López-de-Silanes, and Shleifer 2002). Whatever their justifications and objectives, regulations are likely to have an impact beyond their area of control. Here we examine whether they have an aggregate effect, specifically on economic growth and volatility. Together these variables provide a comprehensive, yet succinct, evaluation of macroeconomic performance.

In assessing the effect of the regulatory environment, it is important to consider that the quality of regulation is profoundly affected by the institutional context in which $\mathfrak{t}$ is imposed. Thus, the ultimate impact that regulation may have on macroeconomic performance is likely to be affected by the country's level of institutional development. In order to explore the interaction between institutional progress and regulatory environment, we extend the basic empirical analysis by allowing the effect of regulation to vary with a measure of governance.

Our empirical analysis also considers the likely endogeneity of the regulatory environment. In particular, economic growth and volatility may shape to some extent the type and strength of regulation imposed in a country. For instance, governments of economies subject to external shocks and associated volatility may want to impose labor constraints in an attempt to protect domestic employment. Also, stagnant economic growth may prompt governments to increase public infrastructure spending, having to

\footnotetext{
${ }^{15}$ See the appendix for a more detailed description of these components.
} 
finance it with a heavier fiscal burden. Although the regulatory environment is likely to be affected by macroeconomic performance, $\mathfrak{t}$ is not clear in what direction and to what extent. In order to identify the effect of regulation on macroeconomic performance, we use instrumental variables that isolate the exogenous variation in regulation.

\section{Sample and specification}

Our empirical methodology is based on cross-country regression analysis. We conduct separate regressions for each dependent variable of interest, namely, economic growth and macroeconomic volatility. In each case, we use as explanatory variables a measure of regulation and a set of basic control variables. All variables included in the empirical exercises are briefly presented below, except the regulation indices that were introduced in the previous section.

Our sample consists of 74 - 76 countries, depending on the regression exercise. In the largest sample, we have 22 developed and 54 developing countries, of which 21 belong to Latin America, 23 to Africa and the Middle East, and 10 to Asia. Country observations for each variable correspond to averages for the 1990s. We are constrained to this decade because internationally comparable regulation measures are available only for this period.

The dependent variables are defined as follows. As is standard in the literature, economic growth is measured as the average annual rate of per capita real GDP growth. Macroeconomic volatility is represented by the standard deviation of the output gap, obtained as the difference between actual and trend per capita real GDP. Trend output is estimated using the band-pass filter of Baxter and King (1999).

As described in the previous section, our explanatory variables of interest are indices that quantify a country's regulatory burden. We consider, in turn, the overall regulation index and its three main components, that is, the product market, labor, and fiscal regulation indices. In an extension to the basic specification, we interact the regulation index with a governance proxy, ${ }^{16}$ which as already noted is constructed from information on experts' perceptions on public accountability, absence of corruption, and rule of law, as reported by the International Country Risk Guide.

\footnotetext{
${ }^{16}$ We don't include governance as a separate explanatory variable because it is highly collinear with the governance-regulation interaction term. If we did it, we would find that neither governance per se nor interacted with regulation is statistically significant.
} 
The instrumental variables, used to isolate the exogenous variation in the regulation indices, are selected considering the recent literature on the determinants of the regulatory environment (see Djankov et al., 2004 and Bolaky and Freund, 2004). They are the initial level of per capita GDP, binary variables that denote legal origin (British, French, German, and Nordic), and proxies for the degree of Western influence based on the fraction of the population that speaks a major European language.

Finally, the set of control variables for the growth regressions consists of the initial level of per capita real GDP (to account for convergence effects), the initial rate of secondary enrollment (as proxy for human capital investment), the initial ratio of private domestic credit to GDP (to account for financial depth), and a Sub-Saharan dummy variable (to control for the particular conditions of civil conflict, mismanagement, and disease affecting this region). ${ }^{17}$ The set of control variables for the volatility regressions represent the major causes of macroeconomic fluctuations, as identified in the literature. They are the standard deviation of terms of trade shocks, a measure of real exchange rate overvaluation, and the frequency of systemic banking crisis.

\section{Results and discussion}

By way of illustration, we show scatter plots that represent the simple relationship between the regulation indices and, respectively, economic growth and macroeconomic volatility (see Figures 3 and 4). The graphs using overall regulation consistently suggest that more heavily regulated economies tend to experience lower economic growth and higher volatility. Observations reflecting poor macroeconomic performance and high overall regulatory burden belong mostly to developing countries, while developed economies tend to occupy the other end of the distribution. The negative link between macroeconomic performance and overall regulation seems to be driven by product market regulation and, to a lesser extent, labor regulation. On the other hand, the connection with the fiscal burden appears to go in the opposite direction, so that fiscally more regulated economies show slightly better performance, although the association is not very strong.

A more formal evaluation of the link between the regulation indices and the measures of macroeconomic performance requires multiple regression analysis, to which

\footnotetext{
${ }^{17}$ The "Africa dummy" has a long tradition in empirical growth studies; see for example Easterly and Levine (1997).
} 
we turn now. The regression results are organized as follows. We first present the results of a basic specification where the regulation indices are taken as independent variables and their effects as unrelated to governance. Then, we allow for the effects of regulation on macro performance to vary with the quality of governance. Finally, keeping the regulation-governance interaction, we further control for the likely endogeneity of the regulation indices through an instrumental variable procedure.

Tables 3 and 4 present the basic specification results on economic growth and macroeconomic volatility, respectively. The overall index of regulation has a negative and significant association with economic growth, and so do the product market and labor regulation indices. The index of fiscal burden has no significant link with economic growth. The results on macroeconomic volatility are similar for overall and product market regulation: both are positively related to volatility. Conversely, labor regulation has no significant link with macroeconomic volatility, and a heavier fiscal burden even appears to be related to lower volatility. Whereas some of these initial results are strengthened in the richer regression specifications discussed next, others change radically --such is the case of the negative connection between the fiscal burden and macroeconomic volatility.

Tables 5 and 6 present the estimation results when we allow for the effect of regulation on growth and volatility to vary with the quality of governance. In the case of economic growth, the overall, product market, and labor regulation indices all carry significantly negative signs and their interaction terms with governance show a positive and significant coefficient. Thus, the negative as sociation of these regulation indices with economic growth appears to be mitigated when the quality of governance rises. Indeed, the point estimates seem to suggest that at the theoretical maximum level of governance quality (equal to one) the impact of product market and labor regulation could even turn positive; however, the test results reported in the last row of Tables 5 and 6 cannot reject the hypothesis that under such optimal governance the impact of regulation is nil. ${ }^{18}$ As for the fiscal burden, neither its direct coefficient nor the coefficient on the interaction term is statistically significant in the growth regression. The results on macroeconomic volatility

\footnotetext{
${ }^{18}$ Note that the impact of regulation under the highest level of governance quality is given by the sum of the coefficients in the first two rows of the tables.
} 
are broadly similar. The overall, product market, and labor regulation indices carry positive and significant coefficients and their corresponding interaction terms with governance have negative signs, which are significant for overall and labor regulation. Again, this evidence is suggestive that good governance moderates the association between heavier regulation and larger volatility. As before, the fiscal burden appears to behave differently from other regulations: Only the interaction term is significant, indicating as before that when the quality of governance is high, heavier fiscal regulation is related to lower volatility.

Tables 7 and 8 report the results when we both allow for the governance-regulation interaction and control for the likely endogeneity of the regulation indices. Given that now reverse causation is controlled for, the interpretation of the regression coefficients goes beyond the mere association between regulation and the indices of macroeconomic performance. The coefficients can now be interpreted as effects of changes in the regulation indices on economic growth and macroeconomic volatility. All regulation indices show a direct negative impact on economic growth, and this impact is statistically significant for all except fiscal regulation. The governance-regulation interaction term carries a significantly positive coefficient in all cases. Therefore, for overall, product market, and labor regulation, we find that a larger regulatory burden brings about a decrease in growth, but such effect is mitigated by better quality of governance. In the case of fiscal regulation, the estimates are less precise but suggest a potentially beneficial impact on growth that drops when the quality of governance quality decreases. Regarding macroeconomic volatility, the direct coefficients on all regulation indices are positive and significant, including the elusive one on fiscal regulation. The interaction term carries a negative coefficient for all regulation indices, but it is significantly so only in the cases of labor and fiscal regulations. Taken together, this means that a heavier burden of overall, product market, labor or fiscal regulation leads to higher macroeconomic volatility, and this harmful effect is mitigated by better governance only in the cases of fiscal and labor regulation.

One potential concern with these results is their sensitivity to outlying observations. Figures 3 and 4 suggest that some countries, such as Sierra Leone, are atypical and may be having an unduly large influence on the estimated parameters. To discard the possibility 
that our results are driven by outliers, we rerun the regressions with the most complete specification for growth and volatility (as in Tables 7 and 8) but excluding clearly atypical cases. We use Cook's ratio as the criterion for exclusion of outliers. Specifically, we exclude the countries whose Cook's ratio consistently exceeds the threshold of 0.1 in our basic regressions. ${ }^{19}$ This threshold turns out to be the value below which the influence of the vast majority of countries on the estimated parameters becomes very similar to each other (see Cook 1979 and Fox 1997). For growth regressions, the potential outliers are Burkina Faso, Nicaragua, and Sierra Leone; and for volatility regressions, they are Nigeria and Sierra Leone. We find that the regressions results without potential outliers are quite similar to the regressions with the original sample. ${ }^{20}$ The coefficient signs remain the same. The magnitude of the coefficients change slightly, usually in the direction of somewhat smaller regulation effects, but their statistical significance improves as they are estimated more precisely. Given that excluding potential outliers does not change the results in any relevant way, we conduct the rest of the analysis using the parameters obtained with the original sample.

How important are the regulation effects economically? Using the point estimates of the regression that accounts for governance interactions and controls for joint endogeneity, we can perform some illustrative exercises. If a country's overall index of regulation was increased by one standard deviation in the cross-country sample (0.13) and its level of governance is equal to the world median (0.44), then its annual rate of per capita GDP growth would decrease by 0.4 percentage points. If a typical developing country were to decrease its product market regulation to the median level of industrial countries (that is, from 0.51 to 0.17 ) while maintaining its level of governance (equal to the median of developing countries, 0.37), then its annual growth rate would rise by about 1.3 percentage points. The point estimates of the coefficients are such that if the quality of governance is sufficiently high, an increase in regulation can have a positive impact on

\footnotetext{
${ }^{19}$ We identify the outliers by applying the Cook's ratio criterion to the OLS regressions only, in accordance with theory. However, once the non-outlier sample is selected, we use it for estimation via instrumental variables.

${ }^{20}$ The results on the sample without potential outliers are not presented in the paper but are available upon request.
} 
growth. $^{21}$ For overall, product market, and labor regulations, this threshold level is quite high, comparable approximately to the quality of governance in the United States or England. Regarding fiscal regulation, the threshold above which an increase in the fiscal burden can have a positive growth impact is smaller and comparable to that of Mexico.

We can perform similar exercises regarding regulation's impact on macroeconomic volatility. If a typical (or median) country in the world experiences a one-standarddeviation increase in the overall index of regulation, its volatility will rise by about $18 \%$. If a typical developing country were to decrease its product market regulation to the median level of industrial countries, its volatility would fall by about $31 \%$. These calculations use the point estimates of the coefficient on the interaction term, even though they are not statistically significant at standard levels for the overall and product market regulation indices. If we were to assume a zero coefficient on the governance-regulation interaction term, the corresponding effects would be considerably larger $(0.28 \%$ and $0.49 \%$, respectively). For labor regulation, the threshold level of governance above which higher regulation decreases volatility is around the $70^{\text {th }}$ percentile, comparable to that of Korea. For fiscal regulation, the volatility-increasing effect would disappear only under a perfect governance score.

\section{Concluding remarks}

Regulation is increasingly viewed as a key explanatory factor for the diversity of aggregate economic performance across countries. In this paper we have provided an empirical assessment of the macroeconomic impact of regulation in a large sample of industrial and developing economies. For this purpose, we have built a set of synthetic regulation indicators encompassing a broad array of regulatory dimensions relevant to firms' economic activity: firm entry, labor, taxation, trade, finance, contract enforcement, and bankruptcy.

These synthetic regulation indicators allow us to characterize the stylized facts concerning regulation around the world. Two main findings emerge in this regard. First,

\footnotetext{
${ }^{21}$ As noted above, however, we cannot reject the hypothesis that the impact of regulation on growth (or volatility, for that matter) is statistically zero when governance is at its maximum (see the test results presented in the last row of Tables 7 and 8).
} 
the burden of regulation shows considerable variation across countries, but in ways that appear systematically related to countries' level of development. Taxes are most heavily regulated in rich countries, while in all other areas developing countries show the harshest regulatory environments. Second, the overall regulatory framework can be conveniently summarized by the extent of regulation in three major dimensions: fiscal, labor and output market, where the latter encompasses the regulation of entry, trade, financial markets, bankruptcy and contract enforcement.

Using this summary representation of the regulatory environment, we have assessed empirically the impact of regulation on two key measures of aggregate performance, namely the growth rate of GDP per capita and the volatility of the output gap. Our estimations take into account the fact that the quality of regulation is likely to vary considerably across countries, reflecting primarily the quality of their overall institutional framework. In addition, we also control for the potential endogeneity of regulation, which could itself be driven in part by aggregate economic performance. This allows us to interpret our empirical results as reflecting the causal impact of regulation on the macroeconomic variables of interest, rather than just mere association between the former and the latter.

On the whole, our estimates suggest that regulation tends to reduce growth. This is clearly the case for product and labor market regulation. In the case of fiscal regulation, however, the results are less conclusive. Regarding macroeconomic volatility, our finding is that all three kinds of regulation tend to increase it. However, the quality of regulation as captured by the overall nstitutional framework - makes a big difference. In most instances we find that better institutions help mitigate, and even eliminate, the adverse impact of regulation on macroeconomic performance.

Does the negative macroeconomic effect of regulations imply that they should be eliminated altogether? As warned in the introduction, this paper does not intend to assess the impact of regulation on social goals that could arguably be beyond the sphere of direct influence of economic growth - broad goals such as social equity and peace, or narrow ones such as worker safety, environmental conservation, and civil security, which typically motivate specific regulations. Thus, our conclusions on the role of regulation must necessarily be weighed in a more comprehensive context before drawing definitive social 
welfare implications. At any rate, to the extent that economic growth and macroeconomic stability are important goals too, our findings imply that streamlining regulation and strengthening governance in highly regulated countries could have a significant payoff in terms of macroeconomic performance. 


\section{Bibliography}

[1] Aghion, P. and P. Howitt, 1992. "A Model of Growth Through Creative Destruction," Econometrica 60, 323-352.

[2] Ahn, Sanghoon, 2001. "Firm Dynamics and Productivity Growth: a Review of Micro Evidence From the OECD," OECD Economics Department.

[3] Ahn, Sanghoon, 2002. "Competition, Innovation and Productivity Growth: a Review of Theory and Evidence," OECD Economics Department Working Paper 317.

[4] Alesina, Alberto, Silvia Ardagna, Giuseppe Nicoletti and Fabio Schiantarelli, 2003. "Regulation and Investment," NBER Working Paper No. 9560.

[5] Barro, Robert and Jong-Wha Lee, 2000. "International Data on Educational Attainment: Updates and Implications," NBER Working Paper No. 7911.

[6] Bassanini, Andrea and Ekkehard Ernst, 2002. "Labor Market Institutions, Product Market Regulations and Innovation: Cross Country Evidence," OECD Economics Department Working Paper 316.

[7] Baxter, Marianne and Robert King, 1999. "Measuring Business Cycles: Approximate Band-Pass Filters for Economic Time Series," Review of Economics and Statistics, November 1999, v. 81, issue 4, pp. 575-93

[8] Bayoumi, Tamim, Douglas Laxton and Paolo Pesenti, 2004. "Benefits and Spillovers of Greater Competition in Europe: a Macroeconomic Assessment," Federal Reserve Bank of New York Staff Report 182.

[9] Bergoeing, Rafael, Norman Loayza and Andrea Repetto, 2004. "Slow Recoveries," NBER Working Paper No. 10584.

[10] Berkowitz, Jeremy and Michelle J. White, 2002. "Bankruptcy and Small Firms' Access to Credit," NBER Working Paper No. 9010.

[11] Blanchard, Olivier and Francesco Giavazzi, 2001. "Macroeconomic Effects of Regulation and Deregulation in Goods and Labor Markets," NBER Working Paper No. 8120.

[12] Blanchard, Olivier and Justin Wolfers, 2000. "Shocks and Institutions in the Rise of European Unemployment: the Aggregate Evidence," Economic Journal 100, 1-33.

[13] Blanchard, Olivier, 2004. "The Economic Future of Europe," forthcoming in Journal of Economic Perspectives.

[14] Bolaky, Bineswaree and Caroline Freund, 2004. "Trade, Regulations, and Growth," Working Paper 3255, The World Bank, Washington DC.

[15] Botero, Juan, Simeon Djankov, Rafael La Porta, Florencio Lopez-de-Silanes and Andrei Shleifer, 2004. “The Regulation of Labor," NBER Working Paper No. 9756.

[16] Business Risk Service Operations Risk Index, 2001-2003. Business Environment Risk Intelligence (BERI), S.A.

[17] Caballero, Ricardo and Mohamad Hammour, 1994. "The Cleansing Effect of Recessions," American Economic Review, 84: 1350-68. 
[18] Caballero, Ricardo and Mohamad Hammour, 1996. "On the Timing and Efficiency of Creative Destruction," Quarterly Journal of Economics.

[19] Caballero, Ricardo and Mohamad Hammour, 1998. "The Macroeconomics of Specificity,” Journal of Political Economy 106, 724-767.

[20] Caballero, Ricardo J., Eduardo Engel and Alejandro Micco, 2004. "Microeconomic flexibility in Latin America," NBER Working Paper No. 10398.

[21] Card, David and Richard B. Freeman, 2002. "What have two decades of British economic reform delivered?" NBER Working Paper 8801.

[22] CEPR-IFS, 2003. "The Link Between Product Market Reform and Macroeconomic Performance," final report ECFIN-E/2002.002.

[23] Claessens, Stijn and Leora Klapper, 2002. "Bankruptcy Around the World: Explanations of its Relative Use," World Bank Working Paper No. 2865, The World Bank, Washington DC.

[24] Cook, R. Dennis, 1979. "Influential Observations in Linear Regression," Journal of the American Statistical Association, 74, 169 -174.

[25] De Soto, Hernando, 1989. The Other Path: The Invisible Revolution in the Third World, HarperCollins.

[26] Djankov, Simeon, Oliver Hart, Tatiana Nenova, and Andrei Shleifer, July 2003. "Efficiency in Bankruptcy," Working Paper, Department of Economics, Harvard University.

[27] Djankov, Simeon, Rafael La Porta, Florencio Lopez-de-Silanes and Andrei Shleifer, 2002. "The Regulation of Entry," Quarterly Journal of Economics, 117, pp. 1-37.

[28] Djankov, Simeon, Rafael La Porta, Florencio Lopez-de-Silanes and Andrei Shleifer, 2003. "Courts," The Quarterly Journal of Economics.

[29] Doing Business, The World Bank, Washington DC.

http://rru.worldbank.org/doingbusiness

[30] Easterly, William and Ross Levine, 1997. “Africa's Growth Tragedy," Quarterly Journal of Economics 112, 1203-1250.

[31] Forteza, Alvaro and Martín Rama, 2001. "Labor Market Rigidity and the Success of Economic Reforms across More than 100 Countries," Paper No. 2521, World Bank Country Economics Department, The World Bank, Washington DC.

[32] Fox, John, 1997. Applied Regression Analysis, Linear Models, and Related Methods. Sage Publications.

[33] Gwartney, James and Robert Lawson, 2002. Economic Freedom of the World - 2002 Annual Report, The Fraser Institute.

[34] Haltiwanger, John, 2000. "Aggregate Growth: What Have We Learned from the Microeconomic Evidence?” OECD Economics Department Working Paper 267.

[35] Heckman, James and Carmen Pagés, 2000. "The Cost of Job Security Regulation: Evidence from Latin American Labor Markets," NBER Working Paper 7773. 
[36] Hopenhayn, Hugo, 1992. "Entry, Exit, and Firm Dynamics in Long Run Equilibrium," Econometrica, Vol. 60 No. 5, pp. 1127-1150.

[37] International Country Risk Guide - ICRG, 1999. Brief guide to the rating system. ICRG, http://www.icrgonline.com

[38] Investment Climate Survey, 2004. The World Bank, Washington DC.

[39] Kaufmann, Dani, Aart Kraay and Pablo Zoido-Lobatón, 1999. "Governance Matters," Policy Research Working Paper No. 2196, The World Bank, Washington, DC.

[40] Klapper, Leora, Luc Laeven and Raghuram G. Rajan, 2004. "Business Environment and Firm Entry: Evidence from International Data," CEPR Discussion Paper DP4366.

[41] Koedijk, Kees and Jeroen Kremers, 1996. "Market Opening, Regulation and Growth in Europe," Economic Policy 23, 445-467.

[42] KPMG, Corporate Tax Rate Survey, March 1998 - January 2003.

[43] La Porta, Rafael, Florencio López-de-Silanes, Andrei Shleifer and Robert Vishny, 1999. "The Quality of Government," The Journal of Law, Economics, and Organization 15, pp. 229-79.

[44] Loayza Norman, Pablo Fajnzylber and César Caderon, 2004. Economic Growth in Latin America and the Caribbean, mimeo, The World Bank, Washington DC.

[45] Loayza, Norman, Ana María Oviedo, Fabio Schiantarelli and Luis Servén, 2004. "Regulation and Firm Dynamics," forthcoming.

[46] Mark A. Dutz and Aydin Hayri, 1999. "Does More Intense Competition Lead to Higher Growth?" CEPR Discussion Paper 2249.

[47] Nicoletti Guiseppe, Andrea Bassanini, Ekkehard Ernst, Sébastien Jean, Paulo Santiago and Paul Swaim, 2001 (b). "Product and Labor Markets Interactions in OECD Countries," OECD Economics Department Working Paper 312.

[48] Nicoletti, Guiseppe and Stefano Scarpetta, 2003. "Regulation, Productivity and Growth: OECD Evidence," Economic Policy 9-72.

[49] Nicoletti, Guiseppe, R.C.G. Haffner, Stephen Nickell, Stefano Scarpetta and G. Zoega, 2001 (a). "European Integration, Liberalization, and Labor Market Performance," in Bertola G., T. Boeri and G. Nicoletti (eds.) Welfare and Employment in United Europe, MIT Press.

[50] Nicoletti, Guiseppe, Stefano Scarpetta and Olivier Boylaud, 2000. "Summary Indicators of Product Market Regulation With an Extension to Employment Protection Legislation," Economics Department Working Paper No. 226, Organisation for Economic Co-operation and Development.

[51] O'Driscoll, Gerald, Edwin Feulner and Mary Anastasia O'Grady, 2003. 2003 Index of Economic Freedom, The Heritage Foundation and The Wall Street Journal.

[52] Pakes Ariel and Paul McGuire, 1994. "Computing Markov-Perfect Nash Equilibria: Numerical Implications of a Dynamic Differentiated Product Model," The RAND Journal of Economics, Vol. 25 No. 4, pp. 555-589. 
[53] Rama, Martin and Raquel Artecona, 2002. "A Database of Labor Market Indicators Across Countries, unpublished," The World Bank, Washington DC.

[54] Shleifer, Andrei and Robert Vishny, 1993. "Corruption," Quarterly Journal of Economics v108, No. 3 (August), pp. 599-617.

[55] The World Bank, 2003. World Development Indicators. Washington DC.

[56] World Bank (2005): World Development Report. Washington DC. 
Table 1: Summary Statistics of Regulation Indices by Region

\begin{tabular}{|c|c|c|c|c|c|c|c|c|c|c|c|}
\hline Indicator & $\begin{array}{l}\text { No. } \\
\text { Obs. }\end{array}$ & Mean & Dev. & Min & Max & Indicator & $\begin{array}{l}\text { No. } \\
\text { Obs. }\end{array}$ & Mean & Dev. & Min & Max \\
\hline \multicolumn{6}{|l|}{ Africa } & \multicolumn{6}{|c|}{ East Asia and Pacific } \\
\hline Entry & 17 & 0.42 & 0.12 & 0.19 & 0.68 & Entry & 6 & 0.31 & 0.12 & 0.17 & 0.51 \\
\hline Financial Mkt. & 17 & 0.54 & 0.14 & 0.32 & 0.81 & Financial Mkt. & 6 & 0.38 & 0.06 & 0.27 & 0.45 \\
\hline Contracts & 17 & 0.63 & 0.20 & 0.37 & 0.99 & Contracts & 6 & 0.43 & 0.10 & 0.29 & 0.60 \\
\hline Trade & 17 & 0.72 & 0.18 & 0.33 & 0.94 & Trade & 6 & 0.54 & 0.24 & 0.34 & 1.00 \\
\hline Labor & 16 & 0.44 & 0.18 & 0.19 & 0.77 & Labor & 6 & 0.37 & 0.18 & 0.13 & 0.54 \\
\hline Fiscal & 17 & 0.50 & 0.13 & 0.31 & 0.75 & Fiscal & 6 & 0.41 & 0.06 & 0.36 & 0.50 \\
\hline Bankruptcy & 12 & 0.49 & 0.15 & 0.32 & 0.74 & Bankruptcy & 5 & 0.52 & 0.18 & 0.28 & 0.76 \\
\hline Product Mkt. & 17 & 0.57 & 0.12 & 0.37 & 0.77 & Product Mkt. & 6 & 0.44 & 0.08 & 0.34 & 0.54 \\
\hline Overall & 17 & 0.54 & 0.10 & 0.37 & 0.70 & Overall & 6 & 0.42 & 0.06 & 0.34 & 0.49 \\
\hline \multicolumn{6}{|l|}{ OECD } & \multicolumn{6}{|c|}{ Latin America and Caribbean } \\
\hline Entry & 22 & 0.18 & 0.11 & 0.01 & 0.37 & Entry & 21 & 0.38 & 0.12 & 0.17 & 0.69 \\
\hline Financial Mkt. & 22 & 0.19 & 0.13 & 0.02 & 0.44 & Financial Mkt. & 21 & 0.43 & 0.18 & 0.11 & 0.79 \\
\hline Contracts & 22 & 0.22 & 0.09 & 0.00 & 0.42 & Contracts & 21 & 0.65 & 0.16 & 0.34 & 0.93 \\
\hline Trade & 22 & 0.11 & 0.07 & 0.00 & 0.28 & Trade & 21 & 0.57 & 0.17 & 0.25 & 0.88 \\
\hline Labor & 21 & 0.44 & 0.17 & 0.13 & 0.78 & Labor & 21 & 0.56 & 0.15 & 0.26 & 0.77 \\
\hline Fiscal & 22 & 0.71 & 0.13 & 0.39 & 0.92 & Fiscal & 21 & 0.36 & 0.12 & 0.10 & 0.53 \\
\hline Bankruptcy & 21 & 0.24 & 0.17 & 0.00 & 0.68 & Bankruptcy & 17 & 0.45 & 0.14 & 0.17 & 0.66 \\
\hline Product Mkt. & 22 & 0.19 & 0.09 & 0.08 & 0.33 & Product Mkt. & 21 & 0.50 & 0.10 & 0.33 & 0.77 \\
\hline Overall & 22 & 0.30 & 0.08 & 0.16 & 0.41 & Overall & 21 & 0.49 & 0.08 & 0.34 & 0.64 \\
\hline \multicolumn{6}{|c|}{ Middle East and North Africa } & \multicolumn{6}{|l|}{ South Asia } \\
\hline Entry & 6 & 0.32 & 0.07 & 0.23 & 0.40 & Entry & 4 & 0.33 & 0.08 & 0.23 & 0.40 \\
\hline Financial Mkt. & 6 & 0.58 & 0.33 & 0.31 & 1.00 & Financial Mkt. & 4 & 0.46 & 0.08 & 0.38 & 0.54 \\
\hline Contracts & 6 & 0.54 & 0.11 & 0.44 & 0.75 & Contracts & 4 & 0.47 & 0.15 & 0.26 & 0.61 \\
\hline Trade & 6 & 0.87 & 0.12 & 0.65 & 1.00 & Trade & 4 & 0.80 & 0.17 & 0.55 & 0.96 \\
\hline Labor & 6 & 0.48 & 0.11 & 0.34 & 0.65 & Labor & 4 & 0.41 & 0.06 & 0.35 & 0.49 \\
\hline Fiscal & 6 & 0.71 & 0.13 & 0.52 & 0.91 & Fiscal & 4 & 0.48 & 0.12 & 0.31 & 0.60 \\
\hline Bankruptcy & 6 & 0.43 & 0.09 & 0.34 & 0.59 & Bankruptcy & 4 & 0.36 & 0.15 & 0.15 & 0.48 \\
\hline Product Mkt. & 6 & 0.55 & 0.08 & 0.49 & 0.67 & Product Mkt. & 4 & 0.48 & 0.04 & 0.42 & 0.53 \\
\hline Overall & 6 & 0.56 & 0.06 & 0.51 & 0.66 & Overall & 4 & 0.47 & 0.03 & 0.42 & 0.50 \\
\hline
\end{tabular}

Source: Authors' estimation 
Table 2: Correlation Coefficients between Regulation Indices

\begin{tabular}{|c|c|c|c|c|c|c|c|}
\hline & Entry & $\begin{array}{l}\text { Financial } \\
\text { Markets }\end{array}$ & $\begin{array}{l}\text { Contract } \\
\text { Enforcement }\end{array}$ & Trade & Bankruptcy & Labor & Fiscal \\
\hline Entry & 1 & & & & & & \\
\hline Financial Markets & $0.6686^{*}$ & 1 & & & & & \\
\hline Contract Enforcement & $0.6747 *$ & $0.6034 *$ & 1 & & & & \\
\hline Trade & $0.6373 *$ & $0.7269 *$ & $0.6246^{*}$ & 1 & & & \\
\hline Bankruptcy & $0.5236^{*}$ & $0.4415^{*}$ & $0.5301 *$ & $0.5078 *$ & 1 & & \\
\hline Labor & $0.4127 *$ & 0.1415 & $0.4665 *$ & 0.0702 & 0.1413 & 1 & \\
\hline Fiscal & $-0.5045^{*}$ & $-0.2824 *$ & $-0.5714^{*}$ & $-0.3386^{*}$ & $-0.3770 *$ & -0.1806 & 1 \\
\hline 1st Princ. Comp. & $0.8594 *$ & $0.7737 *$ & $0.8600 *$ & $0.8551 *$ & $0.7111 *$ & $0.2923 *$ & $-0.5715^{*}$ \\
\hline 2nd Princ. Comp. & 0.1057 & $-0.3769 *$ & 0.1597 & $-0.2823^{*}$ & -0.0274 & $0.9007 *$ & -0.1069 \\
\hline 3rd Princ. Comp. & 0.1605 & $0.3393^{*}$ & -0.0921 & 0.1672 & -0.1536 & $0.2778 *$ & $0.7632 *$ \\
\hline
\end{tabular}

\begin{tabular}{lllll}
\hline & $\begin{array}{l}\text { Product } \\
\text { Market }\end{array}$ & Labor & Fiscal & Overall \\
\hline Product Market & 1 & & & \\
Labor & $0.2914^{*}$ & 1 & & \\
Fiscal & $-0.4985^{*}$ & -0.1806 & 1 & 1 \\
Overall & $0.9678^{*}$ & $0.4445^{*}$ & $-0.3263^{*}$ & 1 \\
\hline 1st Princ. Comp. & $\mathbf{0 . 9 7 9 8 *}$ & $0.2923^{*}$ & $-0.5715^{*}$ & $0.9348^{*}$ \\
2nd Princ. Comp. & -0.1453 & $\mathbf{0 . 9 0 0 7 *}$ & -0.1069 & -0.0037 \\
3rd Princ. Comp. & 0.1131 & $0.2778^{*}$ & $\mathbf{0 . 7 6 3 2 *}$ & $0.3315^{*}$ \\
\hline
\end{tabular}

Notes: * denotes significance at the $5 \%$ level.

Source: Authors' estimation 
Table 3. Economic Growth and Burden of Regulation: Basic Specification

Sample: 74-76 countries, 1990 - 2000

Method of estimation: Ordinary Least Squares

Dependent variable:

Economic growth: Average annual growth rate of GDP per capita, 1990-2000

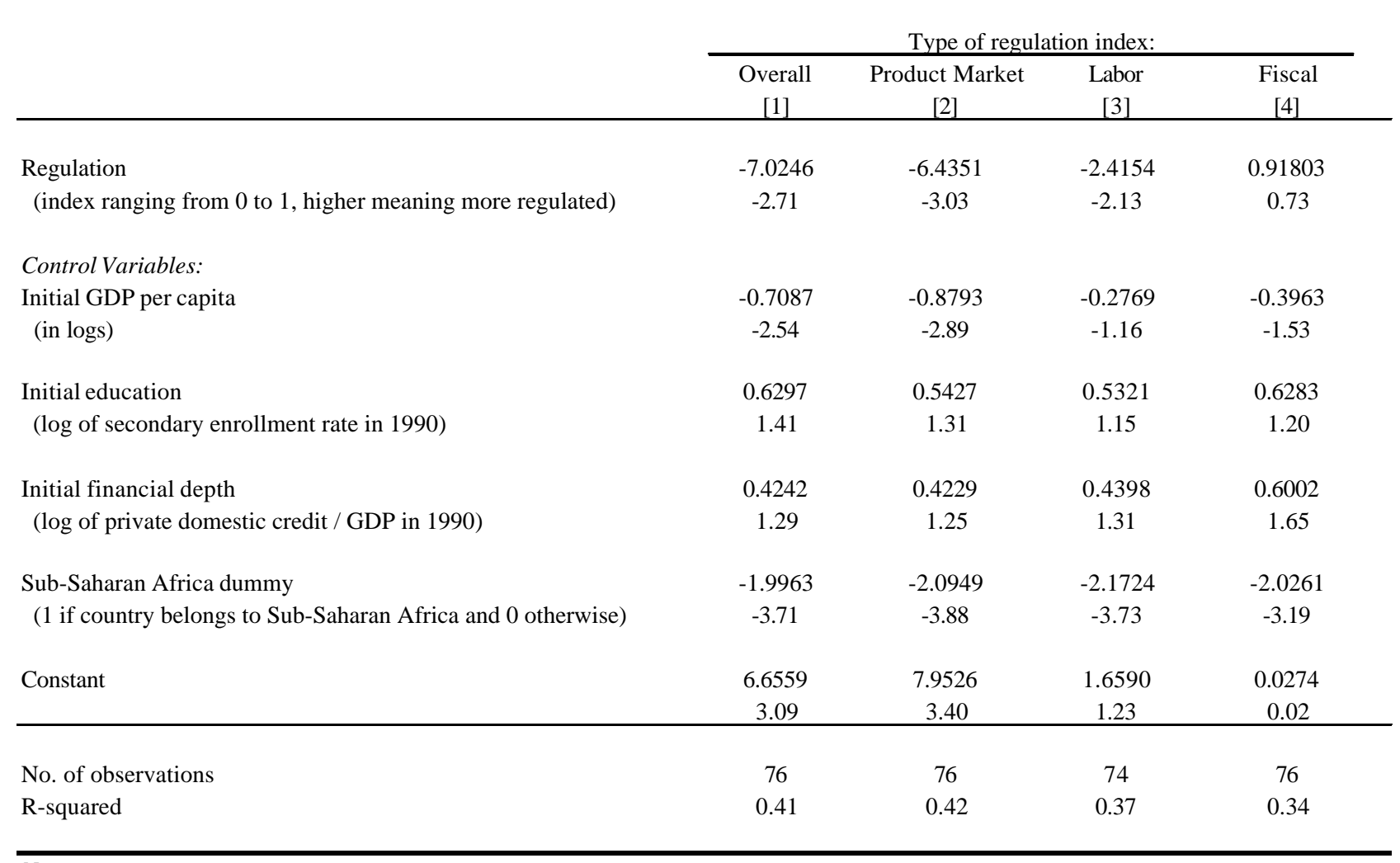

Notes:

a) Standard errors are robust to heteroscedasticity (Newey-West).

b) $t$-Statistics are presented below the corresponding coefficient.

Source: Authors' estimation 
Table 4. Macroeconomic Volatility and Burden of Regulation: Basic Specification

Sample: 74-75 countries, 1990 - 2000

Method of estimation: Ordinary Least Squares

Dependent variable:

Macroeconomic Volatility: Standard deviation of the per capita GDP gap, 1990-2000

\begin{tabular}{|c|c|c|c|c|}
\hline & \multicolumn{4}{|c|}{ Type of regulation index: } \\
\hline & $\begin{array}{c}\text { Overall } \\
{[1]}\end{array}$ & $\begin{array}{c}\text { Product Market } \\
{[2]} \\
\end{array}$ & $\begin{array}{c}\text { Labor } \\
{[3]}\end{array}$ & $\begin{array}{c}\text { Fiscal } \\
{[4]}\end{array}$ \\
\hline Regulation & 0.0289 & 0.0235 & 0.0093 & -0.0112 \\
\hline (index ranging from 0 to 1 , higher meaning more regulated) & 3.12 & 3.30 & 1.03 & -1.68 \\
\hline \multicolumn{5}{|l|}{ Control Variables: } \\
\hline \multirow{2}{*}{$\begin{array}{l}\text { Volatility of terms of trade shocks } \\
\text { (standard deviation of annual terms of trade growth) }\end{array}$} & 0.0004 & 0.0004 & 0.0007 & 0.0007 \\
\hline & 1.76 & 1.32 & 3.37 & 2.66 \\
\hline \multirow{2}{*}{$\begin{array}{l}\text { Real exchange rate overvaluation } \\
\text { (proportional index, where overvaluation if index }>100 \text { ) }\end{array}$} & -0.0004 & 0.0007 & -0.0025 & -0.0005 \\
\hline & -0.10 & 0.20 & -0.67 & -0.13 \\
\hline \multirow{2}{*}{$\begin{array}{l}\text { Systemic Banking Crises } \\
\text { (frequency of years under crisis, ranging from } 0 \text { to } 1 \text { ) }\end{array}$} & -0.0067 & -0.0069 & -0.0071 & -0.0078 \\
\hline & -1.26 & -1.27 & -1.31 & -1.36 \\
\hline \multirow{2}{*}{ Constant } & 0.0055 & 0.0039 & 0.0213 & 0.0233 \\
\hline & 0.31 & 0.22 & 1.22 & 1.37 \\
\hline No. of observations & 75 & 75 & 74 & 75 \\
\hline R-squared & 0.22 & 0.24 & 0.18 & 0.19 \\
\hline
\end{tabular}

Notes:

a) Standard errors are robust to heteroscedasticity (Newey-West).

b) $t$-Statistics are presented below the corresponding coefficient.

Source: Authors' estimation 


\section{Table 5. Economic Growth and Burden of Regulation: Governance Interactions}

Sample: 74-76 countries, 1990 - 2000

Method of estimation: Ordinary Least Squares

Dependent variable:

Economic growth: Average annual growth rate of GDP per capita, 1990-2000

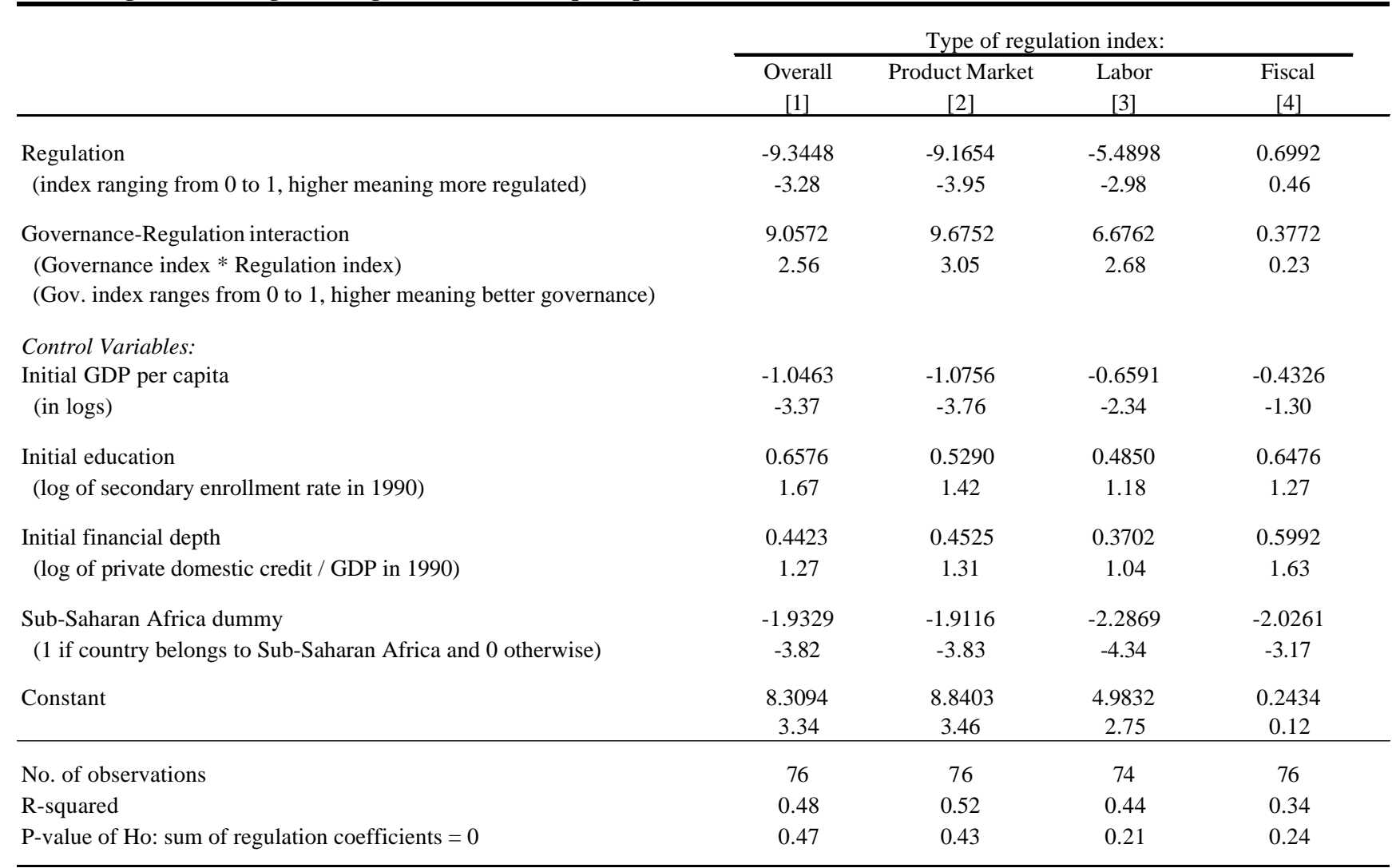

Notes:

a) Standard errors are robust to heteroscedasticity (Newey-West).

b) $t$-Statistics are presented below the corresponding coefficient.

Source: Authors' estimation 
Table 6. Macroeconomic Volatility and Burden of Regulation: Governance Interactions

Sample: 74-75 countries, 1990 - 2000

Method of estimation: Ordinary Least Squares

Dependent variable:

Macroeconomic Volatility: Standard deviation of the per capita GDP gap, 1990-2000

Type of regulation index:

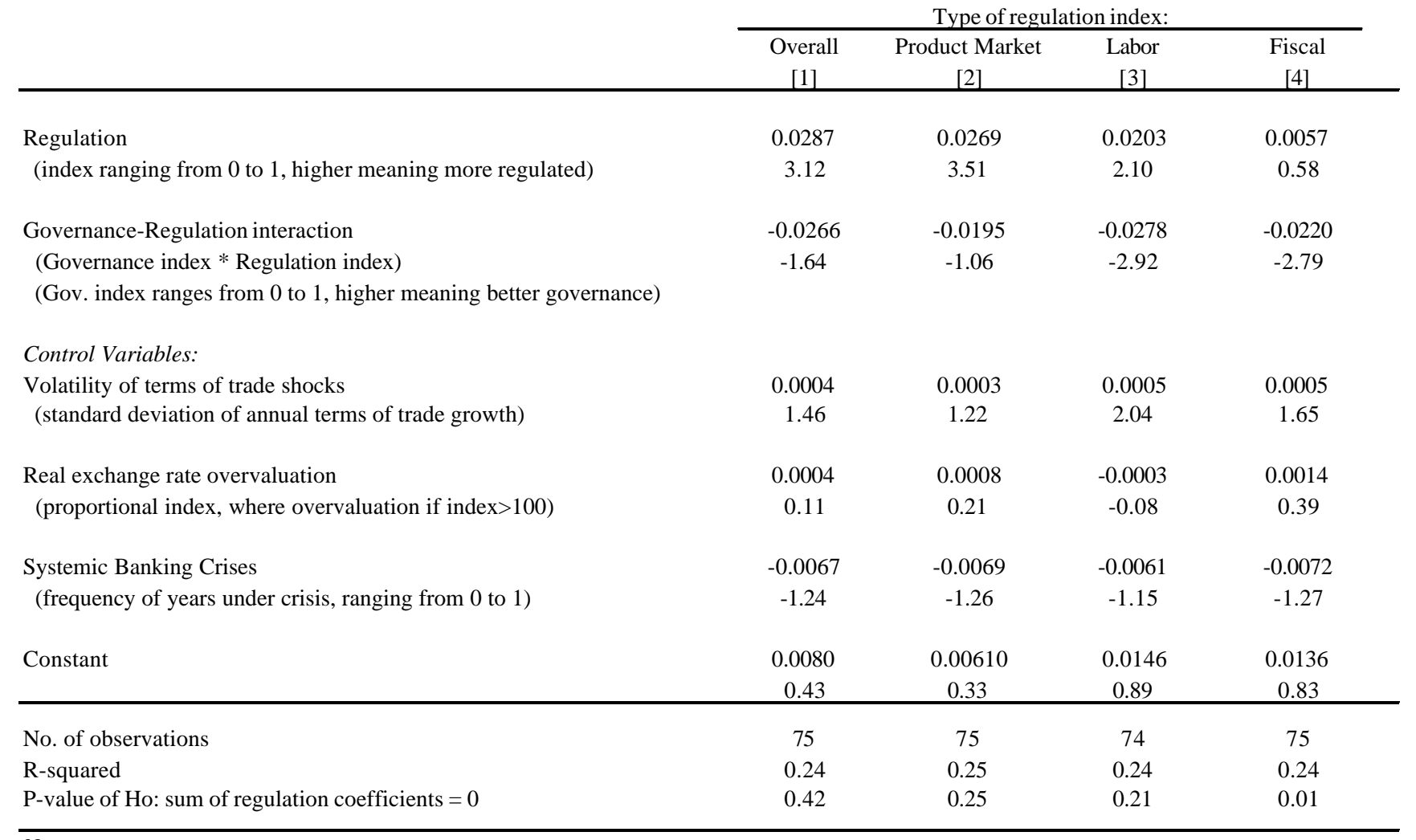

Notes:

a) Standard errors are robust to heteroscedasticity (Newey-West).

b) $t$-Statistics are presented below the corresponding coefficient.

Source: Authors' estimation 
Table 7. Economic Growth and Burden of Regulation: Accounting for endogeneity and governance interactions

Sample: 74-76 countries, 1990 - 2000

Method of estimation: Two-Stage Least Squares

Dependent variable:

Economic growth: Average annual growth rate of GDP per capita, 1990-2000

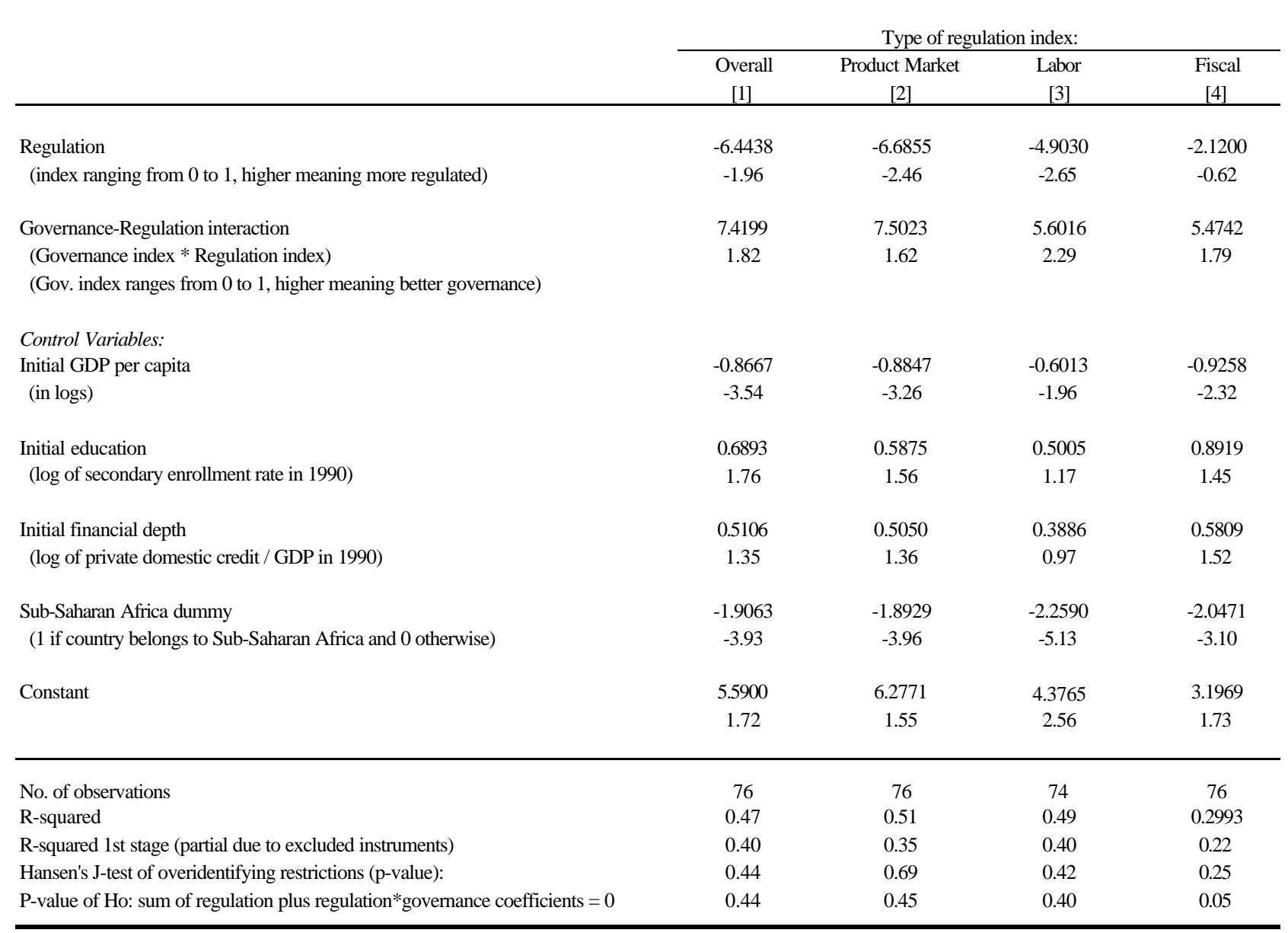

Notes:

a) Standard errors are robust to heteroscedasticity (Newey-West).

b) $t$-Statistics are presented below the corresponding coefficient.

c) Instruments for regulation and interaction: log of per capita GDP in 1990, binary variable of legal origin (British,French, German, Nordic), variables indicating fraction of population that speaks a major European language, and governance index.

Source: Authors' estimation 
Table 8. Macroeconomic Volatility and Burden of Regulation: Accounting for endogeneity and governance interactions

Sample: $74-75$ countries, 1990 - 2000

Method of estimation: Two-Stage Least Squares

Dependent variable:

Macroeconomic Volatility: Standard deviation of the per capita GDP gap, 1990-2000

\begin{tabular}{|c|c|c|c|c|}
\hline & \multicolumn{4}{|c|}{ Type of regulation index: } \\
\hline & $\begin{array}{c}\text { Overall } \\
{[1]}\end{array}$ & $\begin{array}{c}\text { Product Market } \\
{[2]} \\
\end{array}$ & $\begin{array}{c}\text { Labor } \\
{[3]}\end{array}$ & $\begin{array}{c}\text { Fiscal } \\
{[4]}\end{array}$ \\
\hline $\begin{array}{l}\text { Regulation } \\
\text { (index ranging from } 0 \text { to } 1 \text {, higher meaning more regulated) }\end{array}$ & $\begin{array}{c}0.0306 \\
2.75\end{array}$ & $\begin{array}{c}0.0275 \\
3.48\end{array}$ & $\begin{array}{c}0.0184 \\
1.66\end{array}$ & $\begin{array}{c}0.0355 \\
1.83\end{array}$ \\
\hline $\begin{array}{l}\text { Governance-Regulation interaction } \\
\text { (Governance index * Regulation index) } \\
\text { (Gov. index ranges from } 0 \text { to } 1 \text {, higher meaning better governance) }\end{array}$ & $\begin{array}{c}-0.0249 \\
-1.51\end{array}$ & $\begin{array}{l}-0.0271 \\
-1.35\end{array}$ & $\begin{array}{c}-0.0292 \\
-3.11\end{array}$ & $\begin{array}{c}-0.0354 \\
-2.91\end{array}$ \\
\hline $\begin{array}{l}\text { Control Variables: } \\
\text { Volatility of terms of trade shocks } \\
\text { (standard deviation of annual terms of trade growth) }\end{array}$ & $\begin{array}{c}0.0003 \\
1.34\end{array}$ & $\begin{array}{c}0.0003 \\
1.17\end{array}$ & $\begin{array}{c}0.0004 \\
2.00\end{array}$ & $\begin{array}{c}0.0005 \\
1.78\end{array}$ \\
\hline $\begin{array}{l}\text { Real exchange rate overvaluation } \\
\text { (proportional index, where overvaluation if index }>100 \text { ) }\end{array}$ & $\begin{array}{c}0.0005 \\
0.13\end{array}$ & $\begin{array}{c}0.0007 \\
0.21\end{array}$ & $\begin{array}{c}0.0000 \\
0.00\end{array}$ & $\begin{array}{c}0.0001 \\
0.03\end{array}$ \\
\hline $\begin{array}{l}\text { Systemic Banking Crises } \\
\text { (frequency of years under crisis, ranging from } 0 \text { to } 1 \text { ) }\end{array}$ & $\begin{array}{c}-0.0066 \\
-1.28\end{array}$ & $\begin{array}{c}-0.0069 \\
-1.31\end{array}$ & $\begin{array}{c}-0.0061 \\
-1.19\end{array}$ & $\begin{array}{c}-0.0059 \\
-1.05\end{array}$ \\
\hline Constant & $\begin{array}{c}0.0067 \\
0.39\end{array}$ & $\begin{array}{c}0.0075 \\
0.43\end{array}$ & $\begin{array}{c}0.0146 \\
0.93\end{array}$ & $\begin{array}{c}0.0072 \\
0.43\end{array}$ \\
\hline No. of observations & 75 & 75 & 74 & 75 \\
\hline $\begin{array}{l}\text { R-squared } \\
\text { R-squared 1st stage (partial due to excluded instruments) }\end{array}$ & $\begin{array}{l}0.24 \\
0.75\end{array}$ & $\begin{array}{l}0.24 \\
0.78\end{array}$ & $\begin{array}{l}0.23 \\
0.47\end{array}$ & $\begin{array}{l}0.15 \\
0.37\end{array}$ \\
\hline Hansen's J-test of overidentifying restrictions ( $\mathrm{p}$-value): & 0.42 & 0.39 & 0.37 & 0.36 \\
\hline P-value of Ho: sum of regulation plus regulation*governance coefficients $=0$ & 0.31 & 0.31 & 0.19 & 0.46 \\
\hline
\end{tabular}

Notes:

a) Standard errors are robust to heteroscedasticity (Newey-West).

b) $t$-Statistics are presented below the corresponding coefficient.

c) Instruments for regulation and interaction: log of per capita GDP in 1990, binary variables of legal origin (British,French, German, Nordic), variables

indicating fraction of population that speaks a major European language, and governance index.

Source: Authors' estimation 
Figure 1: Regulation around the World

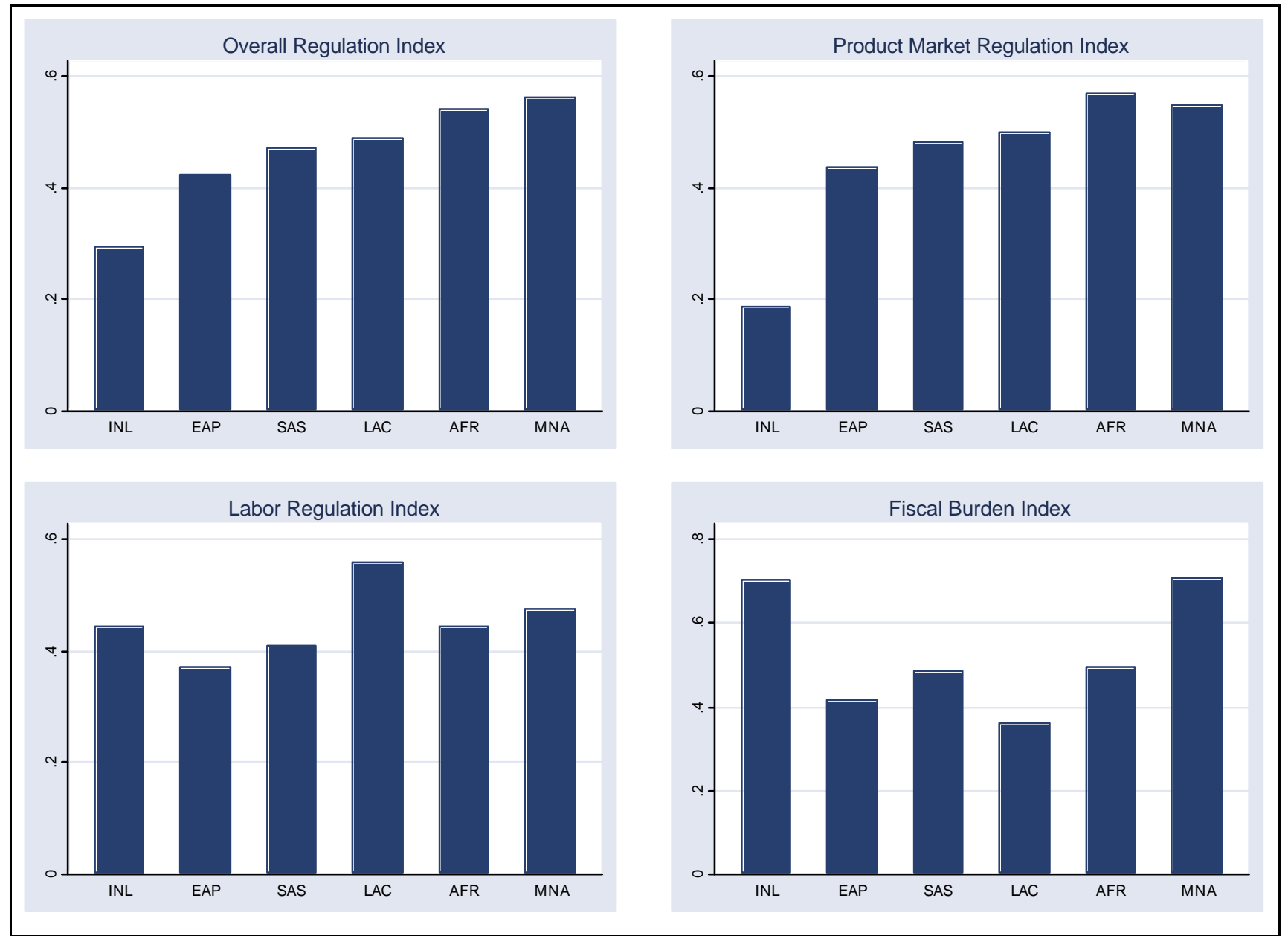

Note: AFR: Africa region, EAP: East Asia and Pacific region, INL: OECD, LAC: Latin America and the Caribbean region, MNA: Middle East and North Africa region, SAS: South Asia region 


\section{Figure 2: GDP per Capita vs. Regulation Indices}
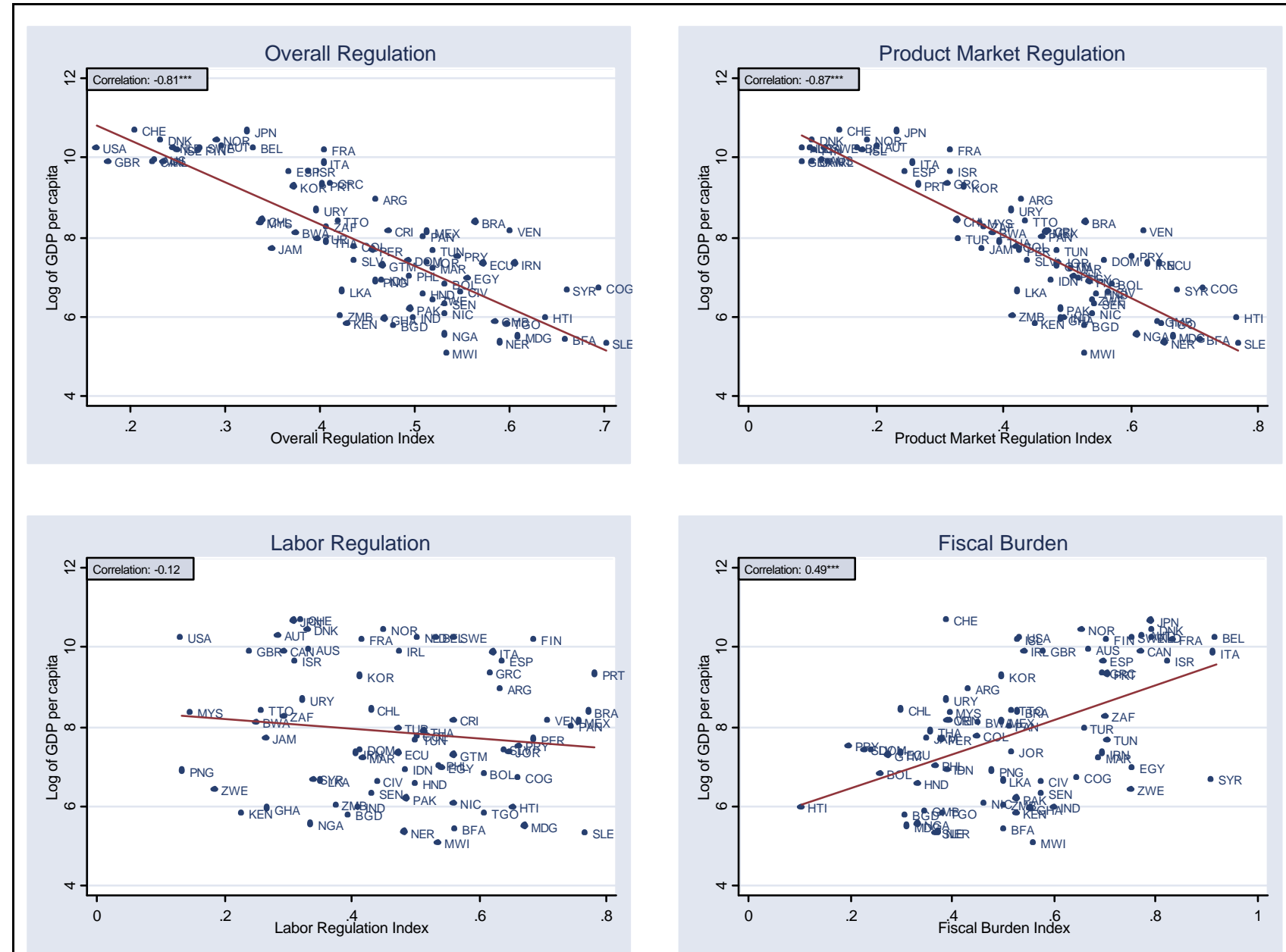

Note: $*, * *$, and $* * *$ denote significance at the $10 \%, 5 \%$, and $1 \%$ level respectively. 
Figure 3: Growth of GDP per Capita vs. Regulation Indices

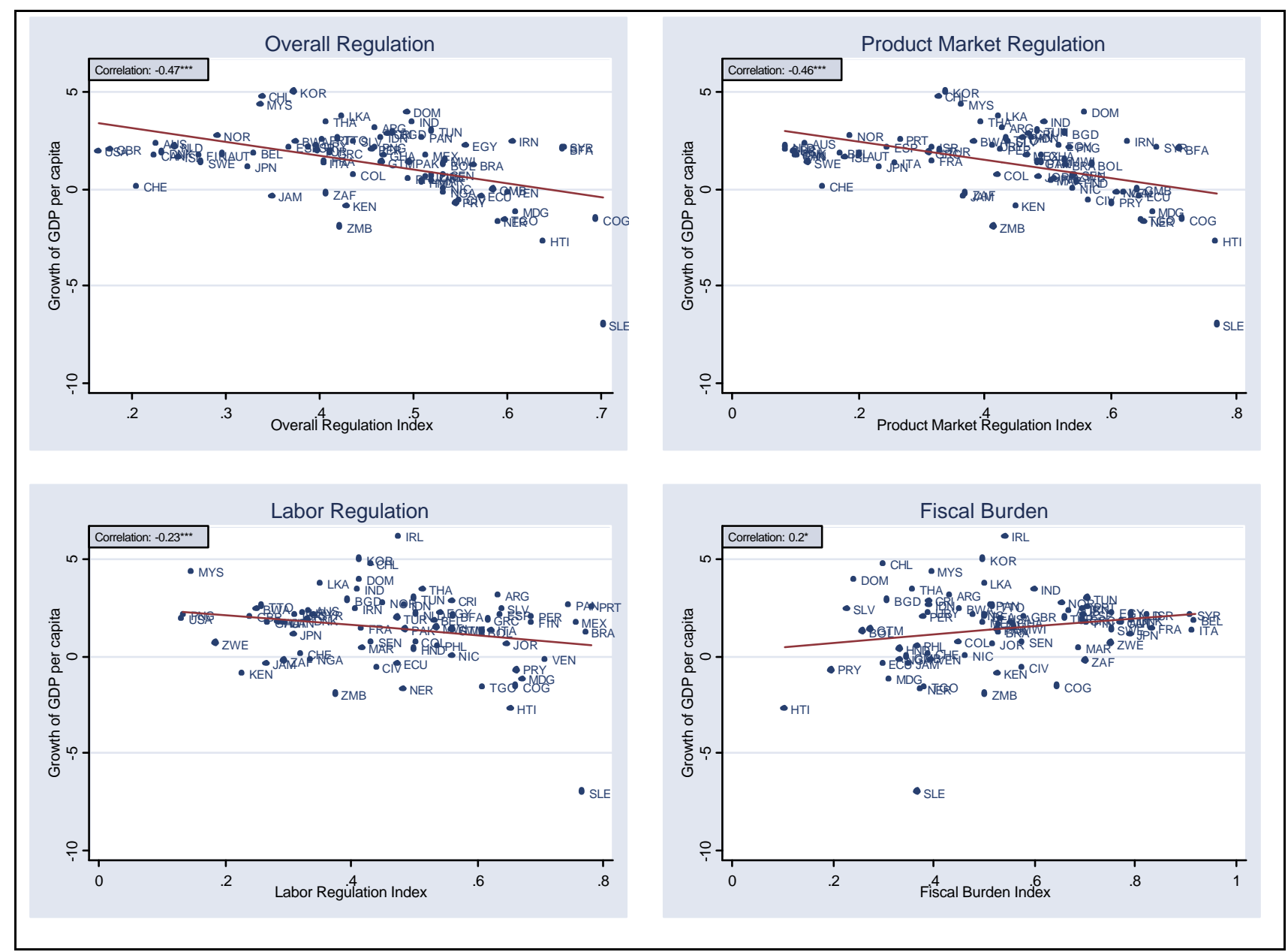

Note: $*, * *$, and $* * *$ denote significance at the $10 \%, 5 \%$, and $1 \%$ level respectively. 
Figure 4: Volatility of Output Gap vs. Regulation Indices

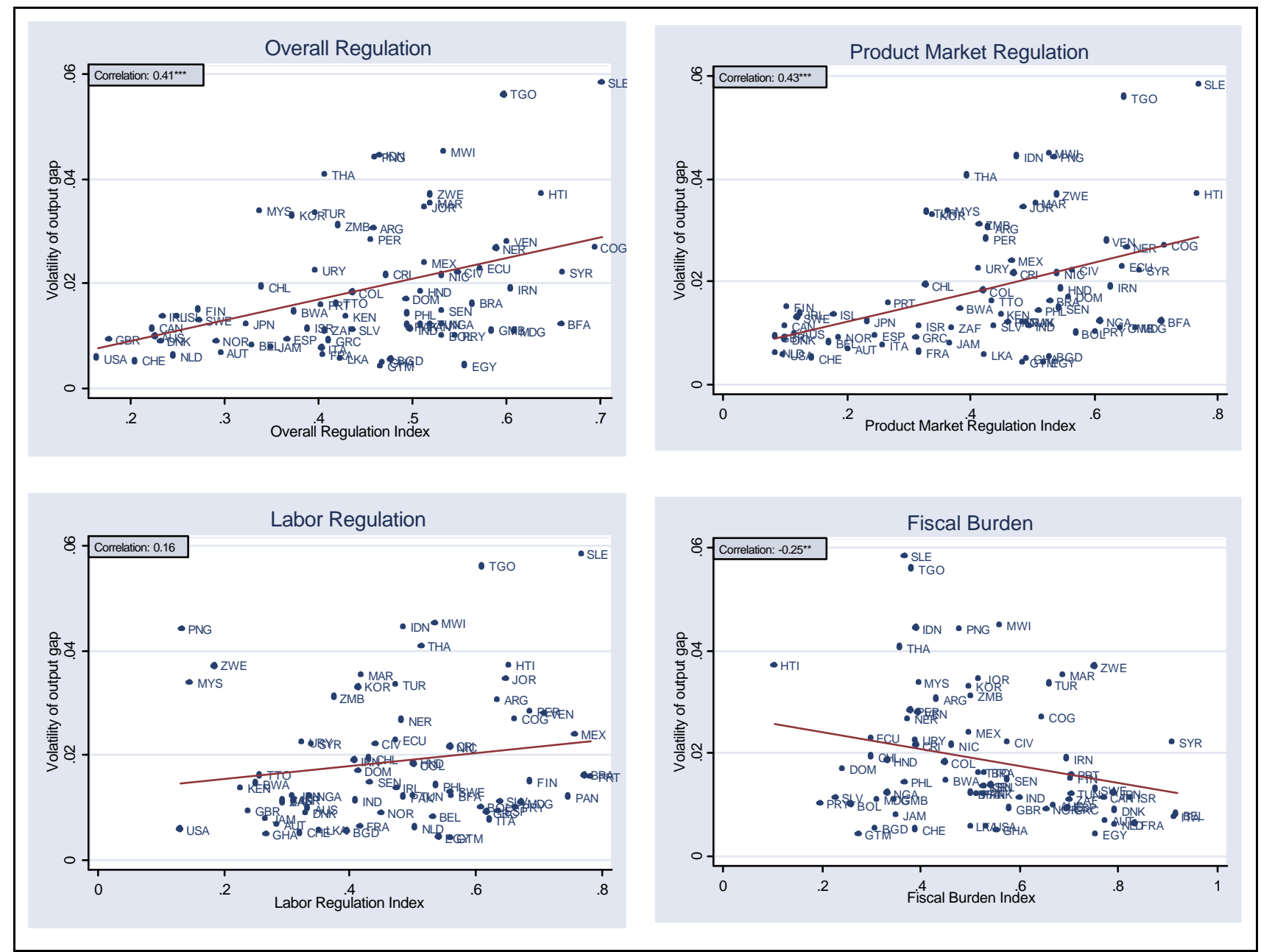

Note: *, **, and $* * *$ denote significance at the $10 \%, 5 \%$, and $1 \%$ level respectively. 


\section{Appendix: Sources and Description of the Regulation Indices' Components}

ENTRY

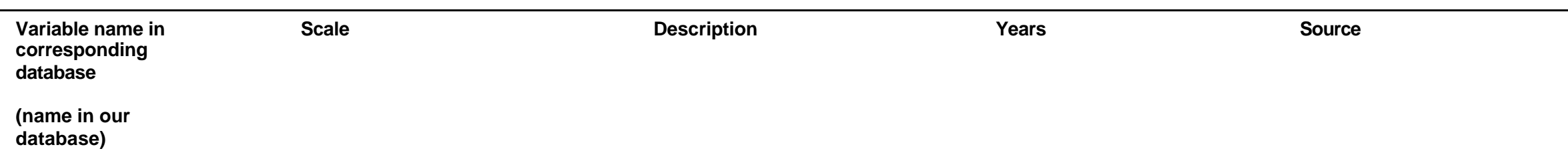

\section{database)}

Number of

Actual number

procedures

comply with in order to obtain a legal status, i.e. to start

(db_entry_proc)

operating as a legal entity. The data cover (1) procedures that are always required; (2) procedures that are generally

Survey

conducted in 1999 ,

updated required but that can be avoided in exceptional cases or for to 2003 exceptional types of businesses.
Time recorded in calendar days. It is assumed that the minimum time required to fulfill a procedural requirement is one day. The variable measures the average duration estimated necessary to complete a procedure. The fastest procedure (independent of cost) is chosen. It is assumed that the entrepreneur completes the procedure in the most efficient way, ignoring the time that the entrepreneur spends in information gathering.

Costs associated with starting-up a business, based on the texts of the Company Law, the Commercial Code, or specific regulations. If there are conflicting sources and the laws are not completely clear, the most authoritative source is used. If the sources have the same rank the source indicating the most costly procedure is used. In the absence of express legal fee schedules, a governmental officer's estimate is taken as an official source. If several sources have different estimates, the median reported value is used. In the absence of government officer's estimates, estimates of incorporation lawyers are used instead. If these differ, the median reported value is computed. In all cases, the cost estimate excludes bribes.

Very low Existing regulations straightforward and applied uniformly to all businesses; regulations not much of a burden for business; corruption nearly nonexistent.

Simple licensing procedures; existing regulations relatively straightforward and applied uniformly most of the time, but burdensome in some instances; corruption possible but rare

\section{Doing Business, The World Bank Group}

see Djankov, La Porta, Lopez-de-Silanes and Shleifer, "The Regulation of Entry", Quarterly Journal of Economics, 117, 1-37, Feb. 2002.

http://rru.worldbank.org/doingbusiness
The Index of Economic Freedom, Heritage Foundation Based on: Economist Intelligence Unit, Country Commerce and Country Report, 2001 and 2002, U.S. Department of State, Country Commercial Guide 24 and Country Reports on Economic Policy and Trade Practices for 2000, Office of the U.S. Trade Representative, 2002 National Trade Estimate Report on Foreign Trade Barriers, and official government publications of each country. 
Complicated licensing procedure; regulations impose substantial burden on business; existing regulations may be applied haphazardly and in some instances are not even published by the government; corruption may be present and poses minor burden on businesses

$4 \quad$ High

Very high Government impedes the creation of new businesses; corruption rampant; regulations applied randomly

TRADE

\begin{tabular}{|c|c|c|c|c|c|}
\hline & \multicolumn{2}{|c|}{ Scale } & Description & Years & Source \\
\hline \multirow[t]{5}{*}{$\begin{array}{l}\text { Trade } \\
\text { (ief_trade) }\end{array}$} & 1 & Very low & Weighted average tariff rate less than or equal to 4 percent. & $\begin{array}{l}1995- \\
2003 \\
\text { (annual) }\end{array}$ & The Index of Economic Freedom, Heritage Foundation \\
\hline & 2 & Low & $\begin{array}{l}\text { Weighted average tariff rate greater than } 4 \text { percent but less } \\
\text { than or equal to } 9 \text { percent }\end{array}$ & & $\begin{array}{l}\text { Based on: The Economist Intelligence Unit, Country } \\
\text { Report and Country Commerce, 2002; International } \\
\text { Monetary Fund, Government Finance Statistics Yearbook }\end{array}$ \\
\hline & 3 & Moderate & $\begin{array}{l}\text { Weighted average tariff rate greater than } 9 \text { percent but less } \\
\text { than or equal to } 14 \text { percent }\end{array}$ & & $\begin{array}{l}\text { and International Financial Statistics on CD-ROM, 2002; } \\
\text { Office of the U.S. Trade Representative, } 2002 \text { National } \\
\text { Trade Estimate Report on Foreign Trade Barriers; U.S. } \\
\text { Department of State, Country Commercial Guide } 3 \text { and }\end{array}$ \\
\hline & 4 & High & $\begin{array}{l}\text { Weighted average tariff rate greater than } 14 \text { percent but } \\
\text { less than or equal to } 19 \text { percent }\end{array}$ & & $\begin{array}{l}\text { Country Reports on Economic Policy and Trade Practices } \\
\text { for } 2001 \text { and 2002; World Bank, Wbrld Development } \\
\text { Indicators 2002; World Trade Organization, Trade Policy }\end{array}$ \\
\hline & 5 & Very high & Weighted average tariff rate greater than 19 percent. & & $\begin{array}{l}\text { publications of each country. For all the European Union } \\
\text { countries, the authors have based the score on data } \\
\text { reported by the World Bank. }\end{array}$ \\
\hline $\begin{array}{l}\text { i Hidden import } \\
\text { barriers } \\
\text { (efw_bi) }\end{array}$ & 0 to 10 & $\begin{array}{l}(0=\text { heavy } \\
\text { regulation })\end{array}$ & No barriers other than published tariffs and quotas. & $\begin{array}{l}1995, \\
2000, \text { and } \\
2001\end{array}$ & $\begin{array}{l}\text { Economic Freedom of the World, The Fraser Institute } \\
\text { From Section: }\end{array}$ \\
\hline $\begin{array}{l}\text { ii Costs of importing } \\
\text { (efw_bii) }\end{array}$ & & & $\begin{array}{l}\text { The combined effect of import tariffs, license fees, bank } \\
\text { fees, and the time required for administrative red-tape }\end{array}$ & & $\begin{array}{l}4 \text { Freedom to Exchange with Foreigners } \\
\text { B. Regulatory Trade Barriers }\end{array}$ \\
\hline
\end{tabular}


raises costs of importing equipment by ( $10=10 \%$ or less; 0 $=$ more than $50 \%$ ). This component is based on survey responses to this question obtained from the Global Competitiveness Report 2000.
Based on: World Economic Forum (2001), Global Competitiveness Report 2001-2002 (Oxford: Oxford Univ. Press).

http://www.freetheworld.com/release.htm

FINANCIAL

MARKETS

\begin{tabular}{|c|c|c|c|c|}
\hline $\begin{array}{l}\text { Variable name in } \\
\text { corresponding } \\
\text { database }\end{array}$ & Scale & Description & Years & Source \\
\hline
\end{tabular}

database)

iv. Avoidance of

interest rate controls

and regulations that

lead to negative real

interest rates

(efw_aiv)

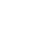

0 to 10

$(0=$ heavy

Data on credit-market controls and regulations were used to construct rating intervals. Countries with interest rater determined by the market, stable monetary policy, and positive real deposit and lending rates received higher ratings. When interest rates were determined primarily by market forces and the real rates were positive, countries were given a rating of 10 . When interest rates were primarily market-determined but the real rates were sometimes slightly negative (less than $5 \%$ ) or the differential between the deposit and lending rates was large $(8 \%$ or more), countries received a rating of 8 . When the real deposit or lending rate was persistently negative by a single-digit amount or the differential between them was regulated by the government, countries were rated at 6 . When the deposit and lending rates were fixed by the government and the real rates were often negative by single-digit amounts, countries were assigned a rating of 4 . When the real deposit or lending rate was persistently negative by a double-digit amount, countries received a rating of 2. A zero rating was assigned when the deposit and lending rates were fixed by the government and real rates were persistently negative by double-digit amounts or hyperinflation had virtually eliminated the credit market.

v. Interest rate

controls

(efw_av)

Banking and finance (ief_banking)

and/or loans are freely determined by the market.

Very low Government involvement in the financial sector negligible; very few restrictions on foreign financial institutions; banks

\author{
1970 \\ 2000 \\ (5-year) \\ and 2001 \\ Economic Freedom of the World, The Fraser Institute \\ From Section: \\ 5: Regulation of Credit, Labor, and Business \\ A. Credit Market Regulations \\ Based on: International Monetary Fund, International \\ Financial Statistics Yearbook (various issues, as well as
} the monthly supplements)

Based on data provided by the World Economic Forum Global Competitiveness Report. very few restrictions on foreign financial instit
may engage in all types of financial services

\section{The Index of Economic Freedom, Heritage Foundation}

Government involvement in the financial sector minimal; few limits on foreign banks; country may maintain some limits on financial services; domestic bank formation may face some barriers
Based on: Economist Intelligence Unit, Country
Commerce, Country Profile, and Country Report for 2001 and 2002; U.S. Department of State, Country Commercial 
Substantial government influence on banks; government owns or controls some banks; government controls credit; domestic bank formation may face significant barriers

$4 \quad$ High

5

Very high Financial institutions in chaos; banks operate on primitive basis; most credit controlled by government and goes only to state-owned enterprises; corruption rampant
Guide 19 ; U.S. Department of State, Country Reports on Economic Policy and Trade Practices for 2001; and official government publications of each country.

\section{CONTRACT ENFORCEMENT}

\begin{tabular}{|c|c|c|c|c|}
\hline $\begin{array}{l}\text { Variable name in } \\
\text { corresponding } \\
\text { database }\end{array}$ & Scale & Description & Years & Source \\
\hline $\begin{array}{l}\text { Number of } \\
\text { procedures } \\
\text { (db_contr_proc) }\end{array}$ & Actual number & $\begin{array}{l}\text { Number of procedures mandated by law or court regulation } \\
\text { that demands interaction between the parties or between } \\
\text { them and the judge or court officer. The questionnaire } \\
\text { covers the step-by-step evolution of a debt recovery case } \\
\text { before local courts in the country's most populous city. }\end{array}$ & $\begin{array}{l}\text { Survey } \\
\text { conducted } \\
\text { in } 1999 \\
\text { updated } \\
\text { to } 2003\end{array}$ & $\begin{array}{l}\text { Doing Business, The World Bank Group. } \\
\text { See Simeon Djankov, Rafael La Porta, Florencio Lopez- } \\
\text { de-Silanes, and Andrei Shleifer, "Courts", Quarterly } \\
\text { Journal of Economics, May 2003. }\end{array}$ \\
\hline $\begin{array}{l}\text { Bureaucracy quality } \\
\text { (icrg_bureau) }\end{array}$ & 0 to 4 & $\begin{array}{l}\text { High points are given to countries where the bureaucracy } \\
\text { has the strength and expertise to govern without drastic } \\
\text { changes in policy or interruptions in government services. } \\
\text { Countries that lack the cushioning effect of a strong } \\
\text { bureaucracy receive low points because a change in } \\
\text { government tends to be traumatic in terms of policy } \\
\text { formulation and day-to-day administrative functions. }\end{array}$ & $\begin{array}{l}1990- \\
2000\end{array}$ & $\begin{array}{l}\text { International Country Risk Guide- PRS Group } \\
\text { http://www.prsgroup.com/icrg/icrg.html }\end{array}$ \\
\hline \multicolumn{5}{|l|}{$\begin{array}{l}\text { FISCAL } \\
\text { REGULATION }\end{array}$} \\
\hline $\begin{array}{l}\text { Variable name in } \\
\text { corresponding } \\
\text { database } \\
\text { (name in our } \\
\text { database) }\end{array}$ & Scale & Description & Years & Source \\
\hline $\begin{array}{l}\text { Fiscal burden } \\
\text { (ief_taxation) }\end{array}$ & Very low & $\begin{array}{l}\text { Individual Income Tax Grading Scale } \\
\text { Top income tax rate } 0 \text { percent. Marginal rate for the } \\
\text { average taxpayer } 0 \text { percent. }\end{array}$ & $\begin{array}{l}1995- \\
2003 \\
\text { (annual) }\end{array}$ & $\begin{array}{l}\text { The Index of Economic Freedom, The Heritage } \\
\text { Foundation }\end{array}$ \\
\hline
\end{tabular}


Top income tax rate greater than 0 percent and less than or equal to 25 percent. Marginal rate for the average taxpayer greater than 0 percent and less than or equal to 10 percent

Moderate

the tax rate greater than 25 percent and less than or equal to 35 percent. Marginal rate for the average taxpayer greater than 10 percent and less than or equal to 15 percent.

High Top income tax rate greater than 35 percent and less than or equal to 50 percent. Marginal rate for the average taxpayer greater than 15 percent and less than or equal to 20 percent.

Very high Top income tax rate greater than 50 percent. Marginal rate for the average taxpayer greater than 20 percent

Corporate Tax Grading Scale

Very low

Low

Moderate

Corporate tax rate less than or equal to 20 percent

Corporate tax rate greater than 20 percent and less than or equal to 25 percent.

Corporate tax rate greater than 25 percent and less than or equal to 35 percent.

Corporate tax rate greater than 35 percent and less than or equal to 45 percent

Very high

Corporate tax rate greater than 45 percent

Government Expenditures Scale for Developed Countries

Very low

Low

Moderate

High

Very high

Very low

Low

Moderate

High

Very high

Less than or equal to 15 percent.

Greater than 15 percent but less than or equal to 25 percent

Greater than 25 percent but less than or equal to 35 percent Greater than 35 percent but less than or equal to 45 percent Greater than 45 percent

Government Expenditures Scale for Developing Countries

Less than or equal to 15 percent

Greater than 15 percent but less than or equal to 20 percent.

Greater than 20 percent but less than or equal to 25 percent

Greater than 25 percent but less than or equal to 30 percent

Greater than 30 percent
Monetary Fund Staff Country Report, Selected Issues and Statistical Appendix, 2000 to 2002; Economist Intelligence Unit, Country Commerce, Country Profile, and Country Report for 2001 and 2002; U.S. Department of State, Country Commercial Guide 9 ; and official government publications of each country. Sources other than Ernst \& Young are noted in the text. For information on government expenditures, the authors' primary sources were Organisation for Economic Co-operation and Monetary Fund, Government Finance Statistics Yearbook for 2001, and International Monetary Fund Staff Country Report, Selected Issues and Statistical Appendix, 2000 to 2002; Standard \& Poor's, Sovereigns Ratings Analysis; Asian Development Bank, Key Indicators of Developing Asian and Pacific Countries 2001; African Development Bank, ADB Statistics Pocketbook 2002; European Bank for Reconstruction and Development, Country Strategies; Inter-American Development Bank; U.S. Department of State, Country Commercial Guide 10 ; and official government publications of each country. Sources other than the OECD and the IMF are noted in the text. 


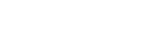

Corporate tax rate. The above rates do not reflect payroll taxes, social security taxes, net wealth taxes, turnover/sales taxes and other taxes not levied on income.

When 2 or more rates are reported, the highest number is chosen.

\author{
1D Top marginal tax \\ rate
}

0 to 10

(efw_d)
Average of 1.D.i. Top Marginal Income Tax Rate and 1.D.ii. Top Marginal Income and Payroll Tax Rate

Countries with higher marginal tax rates that take effect at lower income thresholds received lower ratings. The income threshold data were converted from local currency income threshold data were converted from local currency rates and the US Consumer Price Index).

$1997-$

2003

(annual)

\section{Corporate Tax Rates Survey, KPMG, Switzerland}

The survey (begun in 1993) currently covers 68 countries, including the 30 member countries of the Organization for Economic Cooperation and Development (OECD), and many countries in the Asia Pacific and Latin America regions. Local KPMG tax offices from these countries have contributed to this survey.

$1970-$

2000

(5-year)

and 2001

\section{Economic Freedom of the World, The Fraser Institute}

From Section:

1: Size of government

Based on: Price Waterhouse, Individual Taxes: A Worldwide Summary (various issues)

\section{LABOR}

\begin{tabular}{|c|c|c|}
\hline 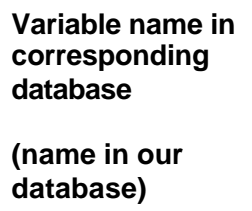 & Scale & Description \\
\hline $\begin{array}{l}\text { TUMMBR } \\
\text { (ra_union) }\end{array}$ & $\%$ & $\begin{array}{l}\text { Total trade union membership, in percent of the total labor } \\
\text { force. Includes workers of both sexes in the public and the } \\
\text { private sectors. In some countries, the union membership } \\
\text { may include unemployed and retired workers who pay their } \\
\text { dues. Based on the number of active contributors declared } \\
\text { by the trade unions themselves and on labor force } \\
\text { estimates. When declared membership is larger than the } \\
\text { labor force, a } 100 \text { percent membership rate is reported. }\end{array}$ \\
\hline $\begin{array}{l}\text { Flexibility-of-hiring } \\
\text { index } \\
\text { (db_flex_hiring) }\end{array}$ & $\begin{array}{l}0 \text { to } 100, \text { higher values } \\
\text { indicating more rigid } \\
\text { regulation }\end{array}$ & Availability of part-time and fixed-term contracts \\
\hline $\begin{array}{l}\text { Conditions-of- } \\
\text { employment index } \\
\text { (db_cond_empl) }\end{array}$ & $\begin{array}{l}0 \text { to } 100 \text {, higher values } \\
\text { indicating more rigid } \\
\text { regulation }\end{array}$ & $\begin{array}{l}\text { Working time requirements, including mandatory minimum } \\
\text { daily rest, maximum number of hours in a normal workweek, } \\
\text { premium for overtime work, restrictions on weekly holiday, } \\
\text { mandatory payment for nonworking days, (which includes } \\
\text { days of annual leave with pay and paid time off for } \\
\text { holidays), and minimum wage legislation. The constitutional } \\
\text { principles dealing with the minimum conditions of } \\
\text { employment are also coded. }\end{array}$ \\
\hline
\end{tabular}

Years

Source

employment are also coded.

\section{$1945-$ \\ 2000 \\ (5 year) \\ A Database of Labor-Market Indicators Across Countries}

M. Rama and R. Artecona, The World Bank, 2002.

\section{Survey Doing Business, The World Bank}

conducted see Botero, Djankov, La Porta, Lopez-de-Silanes, and in 1997, Shleifer, "The Regulation of Labor", Working Paper 9756, updated National Bureau of Economic Research, June 2003

to 2003 Based on: NATLEX database (International Labour Organization); Constitutions, available online on the U.S. Law Library of Congress website; International Encyclopaedia for Labour Law and Industrial Relations, Encyclopaedia for Labour Law and Industrial Relations, Legal advice from leading local law firms was solicited to confirm accuracy in all cases. Following the OECD Job Study and the International Encyclopaedia for Labour Law 
Workers' legal protections against dismissal, including grounds for dismissal, procedures for dismissal (individual and collective), notice period, and severance payment. The constitutional principles dealing with protection against dismissal are also coded. and Industrial Relations, the areas subject to statutory regulation in all countries were identified. Those include hiring of workers, conditions of employment, and firing of workers

\section{BANKRUPTCY}

\begin{tabular}{|c|c|c|c|c|}
\hline 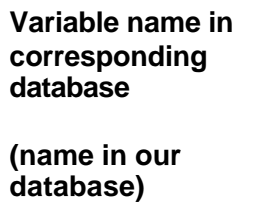 & Scale & Description & Years & Source \\
\hline $\begin{array}{l}\text { Goals-of-insolvency } \\
\text { index } \\
\text { (db_close_insolv) }\end{array}$ & 0 to 100 & $\begin{array}{l}\text { The measure documents the success in reaching the three } \\
\text { goals of insolvency, as stated in Hart (1999). It is calculated } \\
\text { as the simple average of the cost of insolvency (rescaled } \\
\text { from } 0 \text { to } 100 \text {, where higher scores indicate less cost), time } \\
\text { of insolvency (rescaled from } 0 \text { to } 100 \text {, where higher scores } \\
\text { indicate less time), the observance of absolute priority of } \\
\text { claims, and the efficient outcome achieved. A score } 100 \text { on } \\
\text { the index means perfect efficiency. }\end{array}$ & 2003 & $\begin{array}{l}\text { Doing Business, The World Bank } \\
\text { See Djankov, Simeon, Oliver Hart, Tatiana Nenova, and } \\
\text { Andrei Shleifer, "Efficiency in Bankruptcy", working paper, } \\
\text { Department of Economics, Harvard University, July } 2003 .\end{array}$ \\
\hline $\begin{array}{l}\text { Cost measure } \\
\text { (db_close_cost) }\end{array}$ & $\%$ & $\begin{array}{l}\text { Cost is defined as the cost of the entire bankruptcy process, } \\
\text { including court costs, insolvency practitioners' costs, the } \\
\text { cost of independent assessors, lawyers, accountants, etc. } \\
\text { In all cases, the cost estimate excludes bribes. The cost } \\
\text { figures are averages of the estimates in a multiple-choice } \\
\text { question, where the respondents choose among the } \\
\text { following options: } 0-2 \text { percent, } 3-5 \text { percent, } 6-10 \text { percent, } \\
11-25 \text { percent, } 26-50 \text { percent, and more than } 50 \text { percent of } \\
\text { the insolvency estate value. }\end{array}$ & 2003 & \\
\hline $\begin{array}{l}\text { Court-powers index } \\
\text { (db_close_court) }\end{array}$ & 0 to 100 & $\begin{array}{l}\text { The measure documents the degree to which the court } \\
\text { drives insolvency proceedings. It is an average of three } \\
\text { indicators: whether the court appoints and replaces the } \\
\text { insolvency administrator with no restrictions imposed by } \\
\text { law, whether the reports of the administrator are accessible } \\
\text { only to the court and not creditors, and whether the court } \\
\text { decides on the adoption of the rehabilitation plan. The } \\
\text { index is scaled from } 0 \text { to } 100 \text {, where higher values indicate } \\
\text { more court involvement in the insolvency process. }\end{array}$ & 2003 & \\
\hline \multicolumn{5}{|l|}{ GOVERNANCE } \\
\hline $\begin{array}{l}\text { Variable name in } \\
\text { corresponding } \\
\text { database }\end{array}$ & Scale & Description & Years & Source \\
\hline
\end{tabular}




\begin{tabular}{|c|c|c|}
\hline $\begin{array}{l}\text { Corruption } \\
\text { (icrg_corrup) }\end{array}$ & 0 to 6 & $\begin{array}{l}\text { This is an assessment of corruption within the political } \\
\text { system. The most common form of corruption met directly } \\
\text { by business is financial corruption in the form of demands } \\
\text { for special payments and bribes connected with import and } \\
\text { export licenses, exchange controls, tax assessments, police } \\
\text { protection, or loans. Although our measure takes such } \\
\text { corruption into account, it is more concerned with actual or } \\
\text { potential corruption in the form of excessive patronage, } \\
\text { nepotism, job reservations, 'favor-for-favors', secret party } \\
\text { funding, and suspiciously close ties between politics and } \\
\text { business. }\end{array}$ \\
\hline $\begin{array}{l}\text { Law and order } \\
\text { (icrg_laworder) }\end{array}$ & 0 to 6 & $\begin{array}{l}\text { The Law sub-component is an assessment of the strength } \\
\text { and impartiality of the legal system, while the Order sub- } \\
\text { component is an assessment of popular observance of the } \\
\text { law. Thus, a country can enjoy a high rating }-3-\text { in terms } \\
\text { of its judicial system, but a low rating }-1 \text { - if it suffers from } \\
\text { a very high crime rate of if the law is routinely ignored } \\
\text { without effective sanction. }\end{array}$ \\
\hline $\begin{array}{l}\text { Democratic } \\
\text { accountability } \\
\text { (icrg_account) }\end{array}$ & 0 to 6 & $\begin{array}{l}\text { Measure of the government's responsiveness to the people. } \\
\text { The score depends on the type of regime: Alternating } \\
\text { Democracy, Dominated Democracy, De-facto One-party } \\
\text { State, or De-jure One-party State. Higher points are given } \\
\text { to Alternating Democracies (see ICRG for details). }\end{array}$ \\
\hline
\end{tabular}

\section{0- International Country Risk Guide, PRS Group}

to Alternating Democracies (see ICRG for details).

Index on Regulatory Burden

Method

ENTRY

TRADE

FINANCIAL MARKETS

We apply the following standardization formula to each component described above:

CONTRACT

ENFORCEMENT

BANKRUPTCY

$\left(\mathrm{X}_{\mathrm{i}}-\mathrm{X}_{\min }\right) /\left(\mathrm{X}_{\max }-\mathrm{X}_{\min }\right)$ if higher values indicate heavier regulation and

$\left(X_{\max } X_{i}\right) /\left(X_{\max } X_{\min }\right)$ if lower values indicate heavier regulation.

LABOR REGULATION

FISCAL BURDEN

Therefore, all values are distributed between 0 and 1, with higher values denoting heavier regulation.

Next we take the simple average of the components in each category to get the corresponding partial indicator. The overall index on regulatory burden is the simple average of the partial indicators. 